\title{
Performance Analysis of CFRP Composite Strips Confined RC Columns under Axial Compression
}

\author{
J. Raja Murugadoss, ${ }^{1}$ Byung Jae Lee, ${ }^{2}$ Jin Wook Bang, ${ }^{3}$ \\ G. Ganesh Prabhu, ${ }^{1}$ and Yun Yong Kim ${ }^{3}$ \\ ${ }^{1}$ Department of Civil Engineering, KPR Institute of Engineering and Technology, Coimbatore, Tamil Nadu 641 407, India \\ ${ }^{2}$ R\&D Center, JNTINC Co. Ltd., Hwaseong 445-842, Republic of Korea \\ ${ }^{3}$ Department of Civil Engineering, Chungnam National University, Daejeon 305764, Republic of Korea
}

Correspondence should be addressed to Yun Yong Kim; yunkim@cnu.ac.kr

Received 15 October 2014; Revised 27 April 2015; Accepted 27 April 2015

Academic Editor: Filippo Giannazzo

Copyright ( 2015 J. Raja Murugadoss et al. This is an open access article distributed under the Creative Commons Attribution License, which permits unrestricted use, distribution, and reproduction in any medium, provided the original work is properly cited.

In an attempt to mitigate the high cost of FRP composite strengthening, an experimental investigation was carried out that sought to achieve efficient and most favorable FRP strengthening using CFRP composite strips. $50 \mathrm{~mm}$ wide CFRP composite strips were used in two different spacings $(20 \mathrm{~mm}$ and $40 \mathrm{~mm})$ to confine columns. The test results of the column confined with smaller spacing $(20 \mathrm{~mm})$ showed significant restraint of axial deformation of the column and enhanced the strength capacity to a maximum of $99.20 \%$ compared to that of reference column. In contrast, the column confined by strips with larger spacing (40 mm) failed by crushing of concrete alone, which occurred even before the CFRP strips reached their ultimate strain. In addition, the embodied energy that exists in the CFRP strips could not be utilized effectively. The stress and strength enhancement ratio of this present study was compared with the previous research that has been conducted on columns confined with full wrapping. From the obtained results, it is recommended that CFRP strips with a spacing of $20 \mathrm{~mm}$ be used to improve the strength capacity of the RC column; in addition, this wrapping technique provides economic benefits compared to a column confined with full wrapping.

\section{Introduction}

Over the past several decades, the innovative application of FRP composites has gained popularity as a method of upgrading/strengthening the deteriorated RC structures in the construction industry due to their high resistance to corrosion and their high strength-to-weight ratio. In addition, FRP composites are lightweight and durable and have high tensile strength, stiffness, and fatigue strength [1]. The external confinement provided by the FRP composites prevents Poisson's effect and enhances the strength capacity and ultimate strain of the concrete. Deterioration of RC structures can be caused by a variety of factors, including fire, ageing, environmental degradation, cracking, corrosion and yielding of steel, and large deformation because of overloading. Traditionally, steel jacketing using steel plates was often used to improve the performance of an RC column, and the effectiveness of this technique has been demonstrated through various strengthening applications [2-4]. Even though the technique was successful in practice, it had some problems, including the addition of self-weight, corrosion of the steel plate, the need for skilled labour, and a higher cost. In addition, this method can be applied only to the square and rectangular columns and is not possible to apply to the circular columns. The research outcomes of $\mathrm{Wu}$ et al. [2] revealed that the bonding of linear steel jackets was ineffective in providing confinement pressure, and ACI 440.2 R-02 [5] does not recommend this technique due to this fact. In contrast, the use of fibre reinforced polymer (FRP) composites for rehabilitation does not have any of these drawbacks, and moreover, it enables the upgrading of deteriorated members without significantly altering the appearance of the member [6]. The outcomes of most of the pioneer research work carried out by researchers Xiao and Wu [7], Maruyama et al. [8], Toutanji and Deng [9], Chaallal et al. [10], Mukherjee et al. [11], Zaki [12], Yaqub and Bailey [13], Wu et al. [14], 
Park et al. [15], Bouchelaghem et al. [16], Pan et al. [17], Wu et al. [18], Mouring et al. [19], Attari et al. [20], Sun et al. [21], and Sen and Reddy [22] revealed that FRP confinement significantly enhances the strength, stiffness, and ductility of the RC structures. Recently, several researchers [23-26] have performed studies on analytical and numerical modelling of FRP strengthened RC structures subjected to various loads. The strengthening/upgrading of RC columns through fully bonding the external surface with FRP composites has led to the increased utilization of FRP composites, thus increasing the cost of the strengthening technique. Thus, studies should be carried out to identify the most favorable FRP wrapping scheme to improve the performance of the RC column members. In order to resolve this issue, a feasibility investigation was carried out on the utilization of CFRP composites in the form of strips to confine the column. Unlike the aforementioned bonding methods, this approach provides an economical solution. Unidirectional CFRP strips having a width of $50 \mathrm{~mm}$ were used in this study, and the experimental parameters were effective spacing between the CFRP strips and number of CFRP layers. The columns were tested under concentrical compression load, and the tests were performed until failure of the column. The test results of the columns confined by CFRP strips were compared with the previous studies, specifically Abdollahi et al. [27], Au and Buyukozturk [28], Pon et al. [29], Bisby et al. [30], Aire et al. [31], Silva [32], Almusallam [33], Silva and Rodrigues [34], Benzaid et al. [35], Smith et al. [36], Erdil et al. [37], Akogbe et al. [38], Miyauchi et al. [39], Wang and Wu [40], Hosotani et al. [41], Shehata et al. [42], Santarosa et al. [43], Thériault et al. [44], Valdmanis et al. [45], Wang and Wu [46], Wang and Hsu [47], Hadi [48], Punurai et al. [49], Quiertant and Clement [50], Pham et al. [51], Li et al. [52], Siddiqui et al. [53], and Sharma et al. [54] conducted on RC columns externally confined by full wrapping, in terms of stress and strength enhancement ratio.

\section{Experimental Program}

\subsection{Material Properties}

2.1.1. Cement and Aggregates. Locally available ordinary/ commercial Portland cement was used as a binding material. According to IS 8112:2013 [56], the specific gravity of the cement was tested, and the value obtained was about 3.13. Natural river sand passing through $4.75 \mathrm{~mm}$ was used as fine aggregate and crushed blue metal about $10 \mathrm{~mm}$ in size was used as a coarse aggregate. Crushed blue metal jelly is the blue-gray hard stone, bluish in color, which is crushed and used for concrete production in the southern part of India. The sieving analysis of both fine and coarse aggregate was carried out according to IS 2386(1):1963 [57] and the specific gravity of the sand and the coarse aggregate was about 2.48 and 2.67 , respectively.

2.1.2. Steel Reinforcement. Commercial high yield strength deformed (HYSD) bars having a yield strength of $415 \mathrm{~N} / \mathrm{mm}^{2}$ were used as reinforcement. Six $8 \mathrm{~mm}$ diameter bars were used as longitudinal/vertical/main reinforcement for all columns. For rings/stirrups, $6 \mathrm{~mm}$ diameter was used, and the effective spacing between the stirrups was about $100 \mathrm{~mm}$.

2.1.3. Fibre and Matrix Material. A unidirectional carbon fibre called Sikawrap-230 C, fabricated by SIKA India Inc., was used in this study to strengthen the column. Carbon fibre was selected for its superior mechanical and durability properties. The stiffness and tensile strengths of the fibre, as provided by the manufacturer, were $230 \mathrm{GPa}$ and $4300 \mathrm{MPa}$, respectively. The thickness of the fibre was $0.131 \mathrm{~mm}$. It is a fabric type of fibre and can be tailored into any desired shape. An epoxy impregnation resin called Sikadur-330 supplied by SIKA India Inc. was used in this study to make the effective bond between concrete and CFRP. It is a two-part system that includes resin and hardener, and the mixing ratio was $100: 25$ $(\mathrm{B}: \mathrm{H})$.

2.2. Concrete. Based on the aggregated properties obtained according to the aforementioned IS standards, the concrete mix proportions were designed to achieve the strength of $25 \mathrm{~N} / \mathrm{mm}^{2}$ (M25) according to the procedure described in IS 10262:2009 [63]. The mix proportion of the concrete was $1: 1.6: 2.9$. A constant water-to-cement ratio (W/C) was observed for all mixtures, and the value was about 0.40 . A test was performed to determine the 28 days' compressive strength of concrete using $150 \mathrm{~mm} \times 150 \mathrm{~mm} \times 150 \mathrm{~mm}$ cubes. The average concrete strength obtained was about $36.5 \mathrm{Mpa}$.

2.3. Specimen Fabrication. A total of seven columns having a cross-sectional dimension of $125 \mathrm{~mm}$ diameter and a height of $800 \mathrm{~mm}$ were fabricated. Of the six specimens excluding the reference column, three columns were externally confined by $50 \mathrm{~mm}$ width CFRP strips having a spacing of $20 \mathrm{~mm}$, and the remaining three columns were confined with the spacing of $40 \mathrm{~mm}$ using $50 \mathrm{~mm}$ width CFRP strips. The specimen fabrication procedure followed in this study was very similar to the procedure followed in [55]. For concrete mixtures, cement and aggregates were weighed in dry condition and mixed together in a 30-litre omni mixer for 60 seconds. Later, the required amount of water was added and the mixture was mixed together for 180 seconds. With the required cover specified in IS 456-2000, the fabricated reinforcement was placed in the mould. Following this, the mould was filled with concrete layer by layer, and each layer of concrete was effectively compacted by the needle vibrator to ensure the concrete was free from air gaps and flaws. After 24 hours, the moulds were removed and the columns were allowed to membrane-cure for 28 days. Surface preparation of a column is very important to achieve an effective bond between the concrete and FRP composites. Thus, after 28 days' curing, the external surface of all the columns was subjected to sand blasting using coarse sand in order to make the surface rough. After sandblasting, all of the columns were covered with plastic sheets immediately and kept in an airtight room. They were then strengthened with CFRP composite strips with two different wrapping schemes, and the different spacings are shown in Figure 1. Before the columns were strengthened with FRP composites, acetone was used to clean the surface 


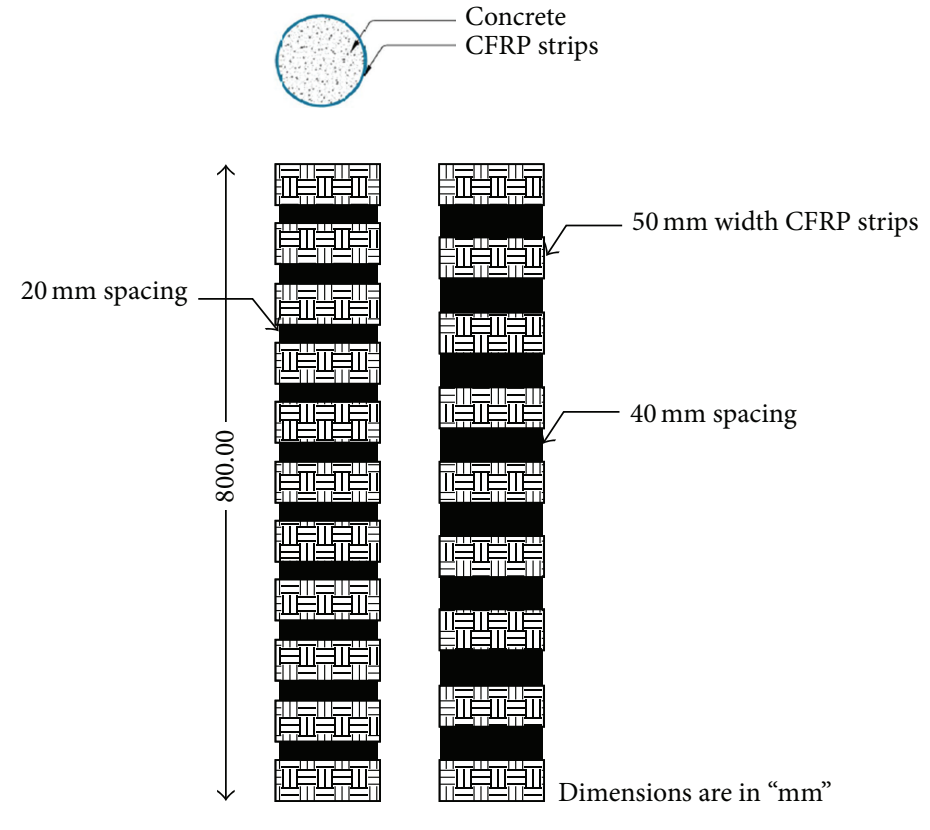

(a)

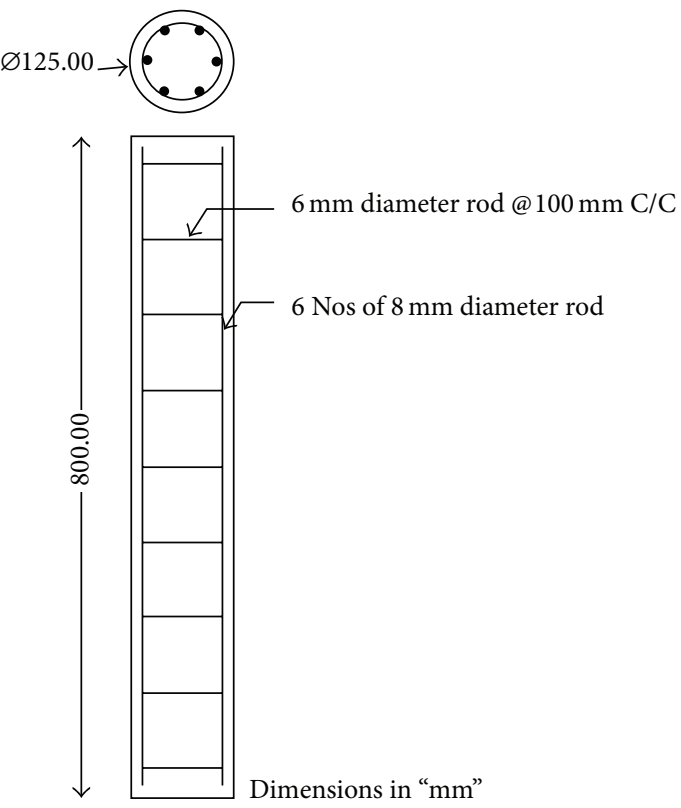

(b)

FIGURE 1: (a) CFRP strips wrapping scheme and (b) column reinforcement details.

to remove the contaminated material, and a steel roller was used in the direction of the fibre to remove the air gaps and excessive resin, as shown in Figure 2.

2.4. Axial Loading Setup. A compression testing machine with a capacity of $2000 \mathrm{kN}$ was used to test the column specimens under concentrically axial compression. The column member was placed on the supports, and care was taken to ensure that its centerline was exactly in line with the axis of the machine. Linear voltage displacement transducers (LVDTs) were used to measure the axial and lateral deformation of the column and the $2000 \mathrm{kN}$ load cell was used to monitor the load. Both load cell and LVDTs were connected to the 16-Channel Data Acquisition System to store the data. The load was applied to the columns using an electronic jack and they were tested until failure. The experimental observation includes the nature of the failure, axial deformation, and ultimate load. To identify the specimens easily and for discussion, the columns were designated with names such as NC-CC, NC-20-1, NC-20-2, NC-20-3, NC-40-1, NC-40-2, and NC-40-3. For example, the name of specimen NC-40-2 specifies that the normal strength column was strengthened by two (2) layers of $50 \mathrm{~mm}$ width CFRP strip with the spacing of $40 \mathrm{~mm}$. The control column is specified as NC-CC.

\section{Results and Discussions}

3.1. Behaviour and Failure Modes. The reference column showed linear behaviour initially; in addition, the first crack was initiated near to the supports at the respective $50 \%$ of its ultimate load. Loading further, the cracks were increased, and new compressive cracks were observed on all sides of the column. Finally, the column failed by crushing of concrete, with concrete spalling observed at the supports occurring at the load of $252 \mathrm{kN}$. It was an explosive failure, accompanied by loud noise, due to the brittle failure of the concrete, as shown in Figure 3. For the column confined with $50 \mathrm{~mm}$ CFRP strips with $20 \mathrm{~mm}$ spacing (NC-20-2 and NC-20-3), at the respective $60 \%(155 \mathrm{kN})$ ultimate load of the reference column (approximately), there were no cracks observed in the unbonded area (on concrete surface); however, a cracking sound was observed due to the removal of excessive resin on the outside of the CFRP strips. Loading further, the columns failed by rupture of fibre followed by crushing of concrete, as shown in Figures 4 to 6; furthermore, it was a very sudden and catastrophic failure when compared to the reference column. As uniform pressure is applied on the top surface of the column, the concrete core expands laterally due to Poisson's effect and this load effect transfers to the CFRP composite strips through adhesion by the shear stress mechanism [64] (see Figure 7). In this way, the load transmitted between column and fibre via the intermediate adhesive layer. The CFRP prevents Poisson's effect on the concrete by providing confining pressure (see Figure 7) and is subjected to tension in the hoop direction, thus enhancing the compressive strength and stiffness of the concrete. Furthermore, the concrete zone near to the CFRP strips becomes more rigid due to the greater confinement pressure exerted by the CFRP strips. When the CFRP strips no longer resist Poisson's effect, rupture of CFRP occurs, followed by the crushing of concrete. The catastrophic failure mode of the strengthened column is attributed to the abrupt absence of confining pressure exerted by the CFRP composites caused 


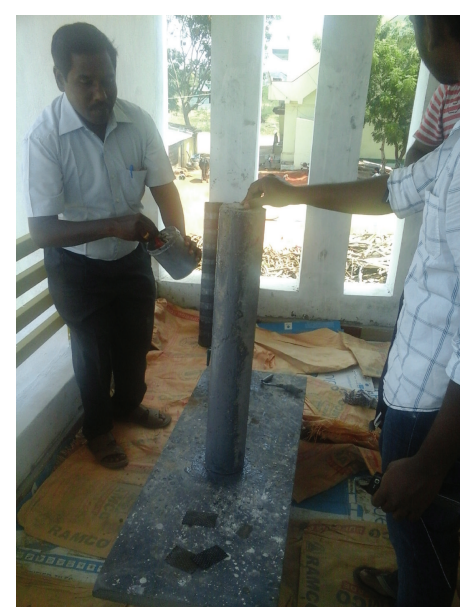

(a)

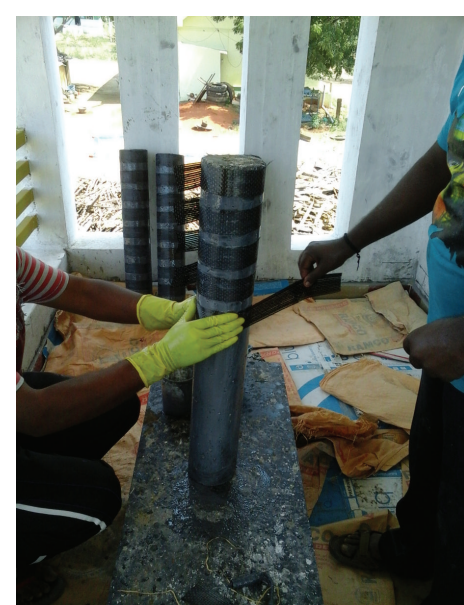

(b)

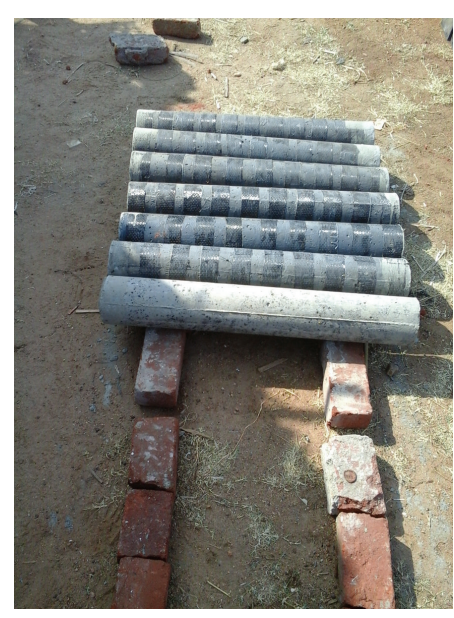

(d)

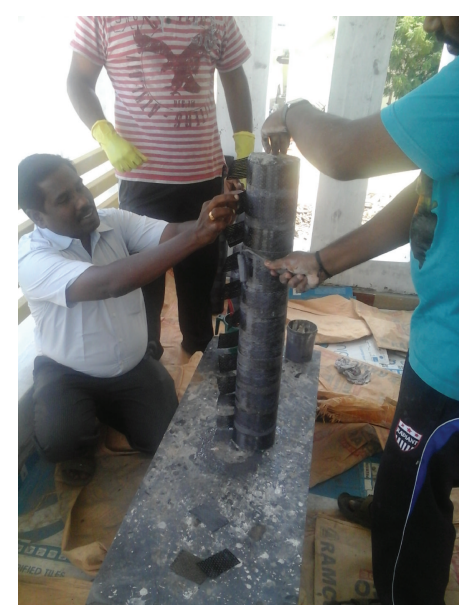

(c)

FIGURE 2: Wrapping procedure [55]: (a) applying resin coating; (b) wrapping CFRP strips; (c) removing excessive resin using steel roller; (d) all strengthened beams.

by the rupture of FRP composites. The increase in the spacing between the CFRP strips from $20 \mathrm{~mm}$ to $40 \mathrm{~mm}$ transforms the failure mode from CFRP rupture to crushing of concrete which occurred in the unbonded area, as shown in Figures 8 to 10 . When the spacing between CFRP strips is increased, the unbonded area is subjected to more strain due to the absence of confining pressure; in addition, the plastic hinges $\left(M_{p}\right)$ were formed on the unbonded area [64] (see Figure 11) due to there being a quite high effective spacing between the FRP strips. As a result, the crushing of concrete occurred on the unbonded area even before the CFRP composites reached their ultimate strain. It was concluded that the embodied energy that exists in the CFRP strips can be effectively utilized when the spacing between the CFRP strips is quite small.

3.2. Axial Stress-Strain Behaviour. The ultimate axial deformation $\left(\Delta_{u}\right)$ and the percentage of enhancement of the restraint effect against the axial deformation of the strengthened column when compared to the reference column are summarized in Table 1. The ultimate axial deformation $\left(\Delta_{u}\right)$ of the column is the axial deformation of the column when the load falls to $80 \%$ of its ultimate load. The lateral confinement provided by the CFRP strips showed positive effects in terms of restraining the deformation of the column at both spacings, as shown in Figures 12 to 14 ; in addition, that restraint effect further promoted the axial stress of the column, which is evident from Figure 14. Column NC-20-1 exhibited quite comparable stress-strain behaviour to the reference column; however, the axial stress was slightly higher than the reference column. Nevertheless, the columns NC-20-2 and NC-20-3 showed a large amount of restraint against axial deformation (see Figure 12) from the initial stage; in addition, a significant improvement in axial stress was observed when compared to the control column. Furthermore, until the respective failure load of the reference column was reached, columns NC-20-2 and NC-20-3 behaved elastically and then started to behave plastically when the load of the columns reached approximately $65 \%$ to $70 \%(240 \mathrm{kN}$ to $351 \mathrm{kN})$ of ultimate 


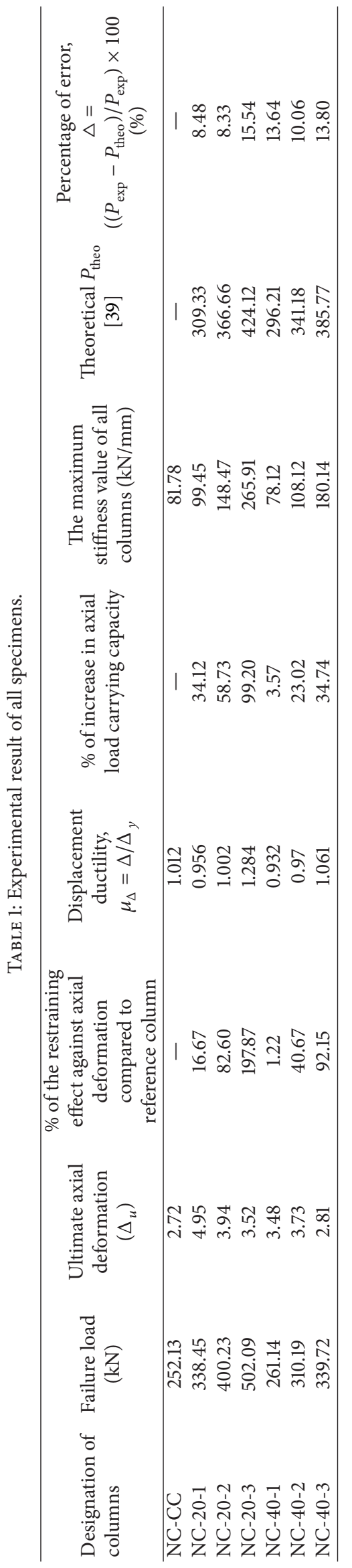




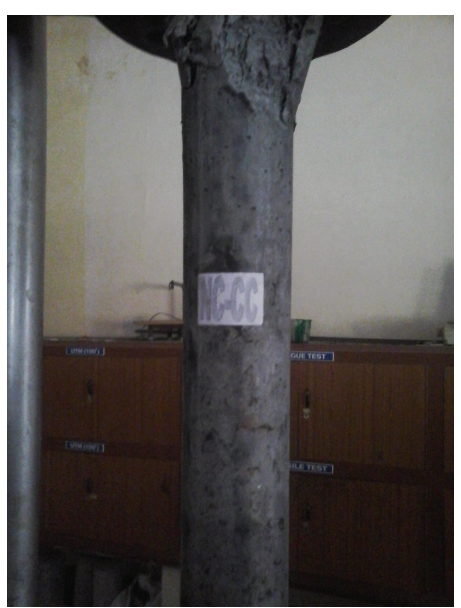

FIGURE 3: Failure pattern of reference column.

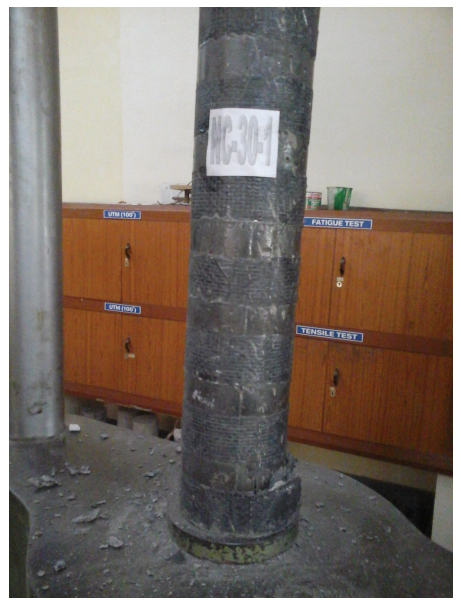

FIGURE 4: Failure pattern of NC-20-1.

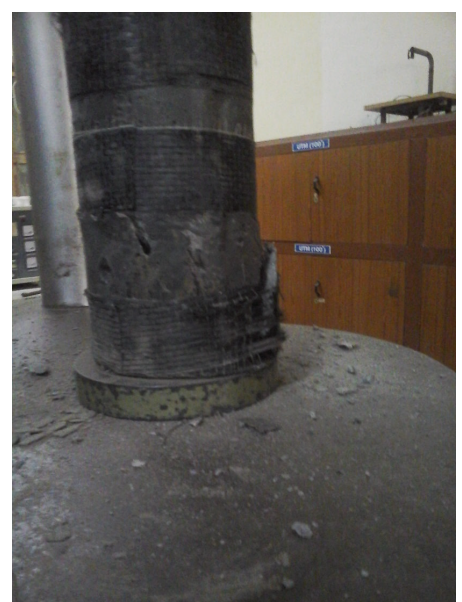

FIGURE 5: Failure pattern of NC-20-2.

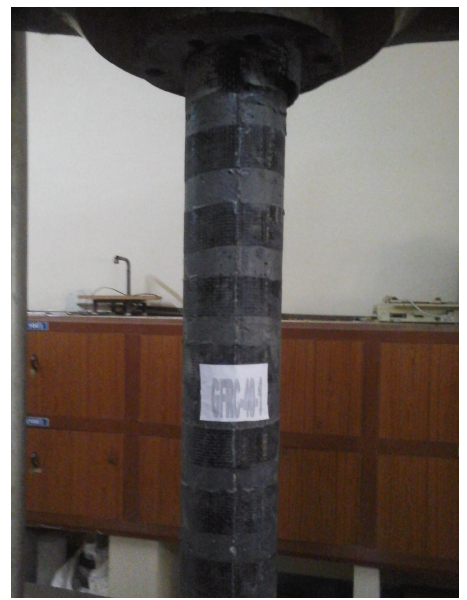

FIGURE 6: Failure pattern of NC-20-3. load. This phenomenon indicates that the increase in the CFRP layers increases the composite plate's thickness, and as a result the confining pressure provided by the CFRP strips increased, significantly controlling Poisson's effect of the concrete, and enhanced the confinement provided by the steel stirrups. It is concluded that a minimum of two layers of CFRP strips should be applied to the RC column in FRP strips strengthening in order to acquire better enhancement of axial deformation control. At the failure load of the reference column, columns NC-20-1, NC-20-2, and NC-20-3 showed an axial deformation of $3.61 \mathrm{~mm}$, $2.34 \mathrm{~mm}$, and $1.41 \mathrm{~mm}$, respectively, which is $16.66 \%, 82.61 \%$, and $197.87 \%$ higher than that of the reference column, respectively. From Figure 15, it can be understood that the enhancement in the restraint of axial deformation was linear when the number of CFRP layers was increased. Compared to columns NC-20-1 and NC-20-2, column NC-20-3 had a restraining effect that was increased by $288.65 \%$ and $152.14 \%$, respectively. It was observed that the column confined with $40 \mathrm{~mm}$ spacing (NC-40-1, NC-40-2, and NC-40-3) showed inferior effects (see Figures 13 and 14) in terms of restraining axial deformation due to the increased spacing between the CFRP strips. Column NC-40-1 did not show any axial deformation control; in addition, the stress-strain behaviour of the column was very similar to that of the reference column (see Figure 13). As discussed earlier, the absence of confining pressure in the unbonded area and the increased effective spacing between the FRP strips led to the formation of plastic hinges $\left(M_{p}\right)$ on the unbonded area (see Figure 11). As a result, the crushing of concrete occurred, even before the CFRP strips reached their ultimate strain. Thereby, the embodied energy existing in the CFRP strips has not been effectively utilized. Columns NC-40-2 and NC-40-3 showed a $40.61 \%$ and $75.12 \%$ enhancement in deformation control, respectively, at the failure load of the reference column. From Figure 14, it can be understood that column NC-40-3 showed equal stress-strain behaviour to that of column NC-20-1. This tendency indicates that the formation of a restraint effect against axial deformation depends upon the effective spacing between the CFRP strips.

The test results of the columns confined by CFRP strips were compared with the previous studies conducted 


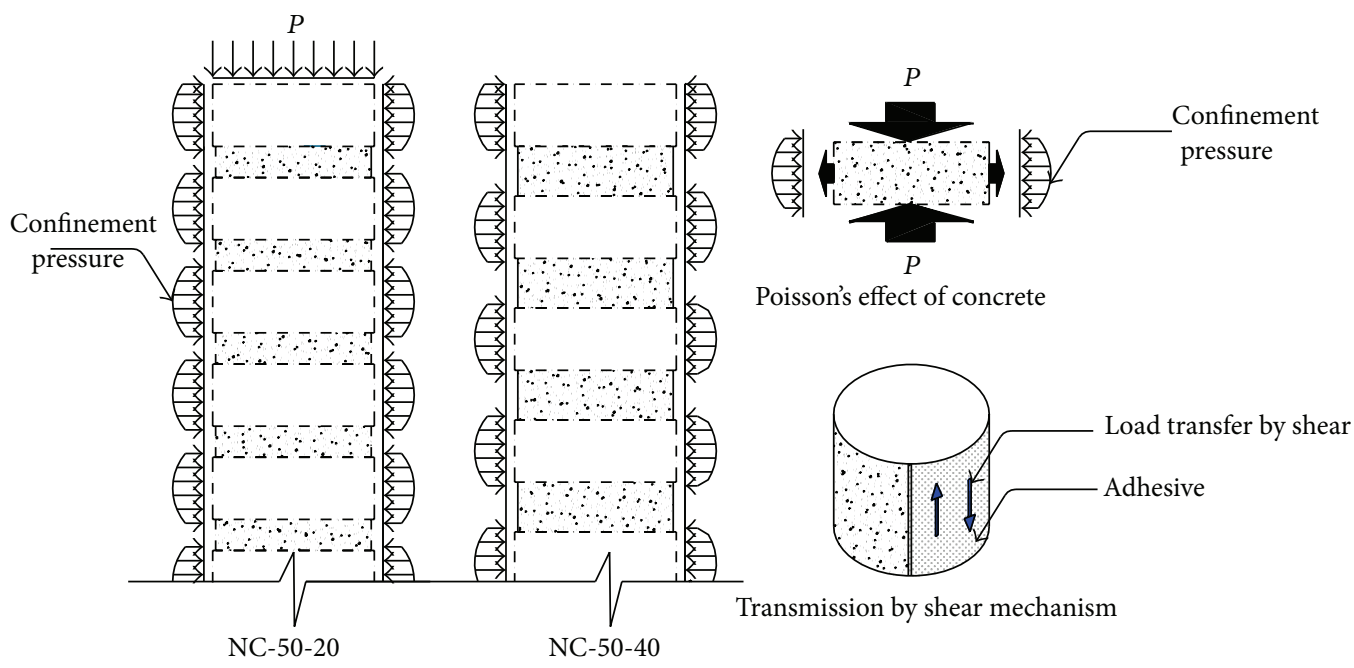

FIgURE 7: Confinement provided by CFRP strips and transmission by shear mechanism.

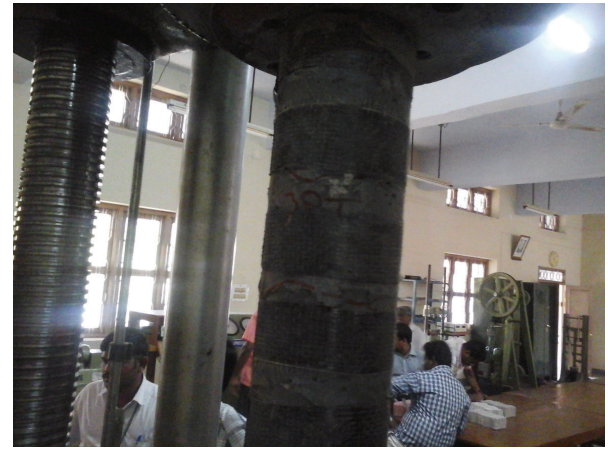

FIgURE 8: Failure pattern of NC-40-1.

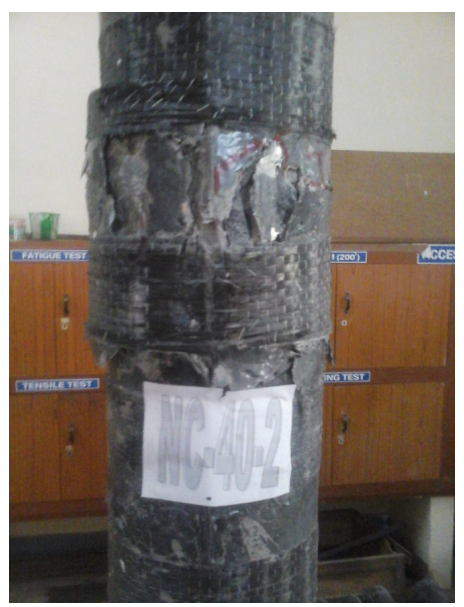

FIgURE 9: Failure pattern of NC-40-2.

on RC columns externally confined by full wrapping, in terms of stress and strength enhancement ratio. Among these studies, few studies were performed on plain concrete confined using different types of FRP with different strengths and modulus. The stress enhancement ratio of some of

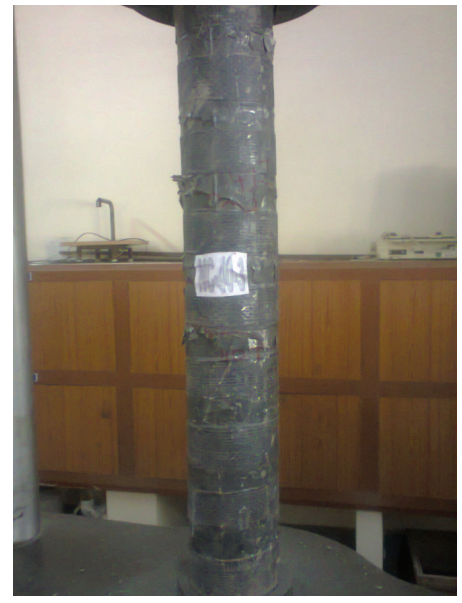

Figure 10: Failure pattern of NC-40-3.

the previous studies conducted on RC columns externally confined by full wrapping is summarized in Table 2 and the results were compared with the present study as is shown in Figure 16. From Figure 16, it can be understood that the stress enhancement ratio value in the present study is essentially equal to the previous studies [27-46]; in addition, in many cases $[28,30-33,35-37,40-42,45]$ the stress enhancement ratio value of the present study was quite high. From this, it can be concluded that wrapping with the strips rather than conventional wrapping can be used to enhance the stress capacity of the RC columns, while providing an economic advantage.

3.3. Ductility Performance. The displacement ductility index of the FRP confined column is an important structural property due to the rupture and catastrophic failure mode of the FRP composites. From the idealized bilinear curve obtained from the load deformation behaviour of the column, the displacement ductility index of all the columns was 
TABLE 2: Test results of previous studies: stress enhancement ratio.

\begin{tabular}{|c|c|c|c|c|c|c|}
\hline Paper & $\begin{array}{l}\text { Diameter of the } \\
\text { column, } D \\
(\mathrm{~mm})\end{array}$ & $\begin{array}{l}\text { Height of the } \\
\text { column, } \\
H(\mathrm{~mm})\end{array}$ & $\begin{array}{c}\text { Compressive stress } \\
\text { value of unconfined } \\
\text { column } \\
\left(f_{\text {sucon }}\right), \mathrm{N} / \mathrm{mm}^{2}\end{array}$ & $\begin{array}{c}\text { Confinement } \\
\text { type }\end{array}$ & Type of fibre & $\begin{array}{c}\text { Stress } \\
\text { enhancement ratio, } \\
f_{\text {scc }}^{\prime} / f_{\text {sucon }}\end{array}$ \\
\hline $\begin{array}{l}\text { Abdollahi et al. } \\
{[27]}\end{array}$ & 150 & 300 & 41.7 & Full wrap & $\begin{array}{l}\text { Normal } \\
\text { modulus } \\
\text { CFRP }\end{array}$ & 3.32 \\
\hline $\begin{array}{l}\text { Au and } \\
\text { Buyukozturk [28] }\end{array}$ & 150 & 375 & 24.2 & Full wrap & GFRP & 1.81 \\
\hline Pon et al. [29] & 150 & 1200 & 9.6 & Full wrap & CFRP & 3.26 \\
\hline Bisby et al. [30] & 150 & 300 & 34.4 & Full wrap & CFRP & 1.28 \\
\hline Aire et al. [31] & 150 & 300 & 42 & Full wrap & $\begin{array}{l}\text { CFRP and } \\
\text { GFRP }\end{array}$ & 2.57 \\
\hline Silva [32] & 150 & 750 & 26.21 & Full wrap & $\begin{array}{l}\text { Normal } \\
\text { modulus } \\
\text { CFRP }\end{array}$ & 1.56 \\
\hline Almusallam [33] & 150 & 300 & 50.80 & Full wrap & $\begin{array}{l}\text { Normal } \\
\text { modulus } \\
\text { CFRP }\end{array}$ & 2.10 \\
\hline $\begin{array}{l}\text { Silva and } \\
\text { Rodriguez [34] }\end{array}$ & 250 & 750 & 31.2 & Full wrap & CFRP & 3.03 \\
\hline Benzaid et al. [35] & 160 & 320 & 49.5 & Full wrap & $\begin{array}{l}\text { Normal } \\
\text { modulus } \\
\text { CFRP }\end{array}$ & 2.55 \\
\hline Smith et al. [36] & 250 & 500 & 35 & Full wrap & CFRP & 1.69 \\
\hline Erdil et al. [37] & 150 & 300 & 20.8 & Full wrap & CFRP & 2.96 \\
\hline Akogbe et al. [38] & 300 & 600 & 26.5 & Full wrap & CFRP & 3.19 \\
\hline $\begin{array}{l}\text { Miyauchi et al. } \\
\text { [39] }\end{array}$ & 100 & 200 & 31.2 & Full wrap & CFRP & 3.26 \\
\hline $\begin{array}{l}\text { Wang and } \mathrm{Wu} \\
{[40]}\end{array}$ & 150 & 300 & 30.9 & Full wrap & CFRP & 2.41 \\
\hline $\begin{array}{l}\text { Hosotani et al. } \\
{[41]}\end{array}$ & 200 & 600 & 41.72 & Full wrap & CFRP & 2.23 \\
\hline Shehata et al. [42] & 225 & 450 & 34 & Full wrap & CFRP & 2.41 \\
\hline $\begin{array}{l}\text { Santarosa et al. } \\
\text { [43] }\end{array}$ & 150 & 300 & 28.1 & Full wrap & CFRP & 3.05 \\
\hline $\begin{array}{l}\text { Thériault et al. } \\
\text { [44] }\end{array}$ & 304 & 608 & 37 & Full wrap & $\begin{array}{l}\text { CFRP and } \\
\text { GFRP }\end{array}$ & 3.89 \\
\hline $\begin{array}{l}\text { Valdmanis et al. } \\
\text { [45] }\end{array}$ & 150 & 300 & 44.3 & Full wrap & CFRP & 2.60 \\
\hline $\begin{array}{l}\text { Wang and Wu } \\
{[46]}\end{array}$ & 194 & 582 & 51.6 & Full wrap & AFRP & 3.37 \\
\hline Present study & 125 & 800 & 20.54 & $\begin{array}{l}\text { Strip wrap } \\
(20 \mathrm{~mm} \\
\text { spacing })\end{array}$ & $\begin{array}{l}\text { Normal } \\
\text { modulus } \\
\text { CFRP }\end{array}$ & 2.99 \\
\hline
\end{tabular}

$f_{\text {scc }}^{\prime}$ : stress value of FRP confined column.

evaluated [4] using (1), where $\mu_{\Delta}$ is the ductility index of the column; $\Delta$ is the axial deformation of the column when the load falls to $85 \%$ of the ultimate load; $\Delta_{y}$ is the deformation at the respective yield load of the column (deformation at the respective load falls to $75 \%$ of the ultimate load):

$$
\mu_{\Delta}=\frac{\Delta}{\Delta_{y}} .
$$

The evaluated displacement ductility index of the strengthened columns has ranged from 0.93 to 1.28 . From Figure 17, it can be understood that the presence of CFRP strips enhances the ductility performance of the column; however, the enhancement was not significantly higher. In addition, the increase in the effective spacing between the CFRP strips decreases the displacement ductility index of the column. The columns confined with three layers in $20 \mathrm{~mm}$ 


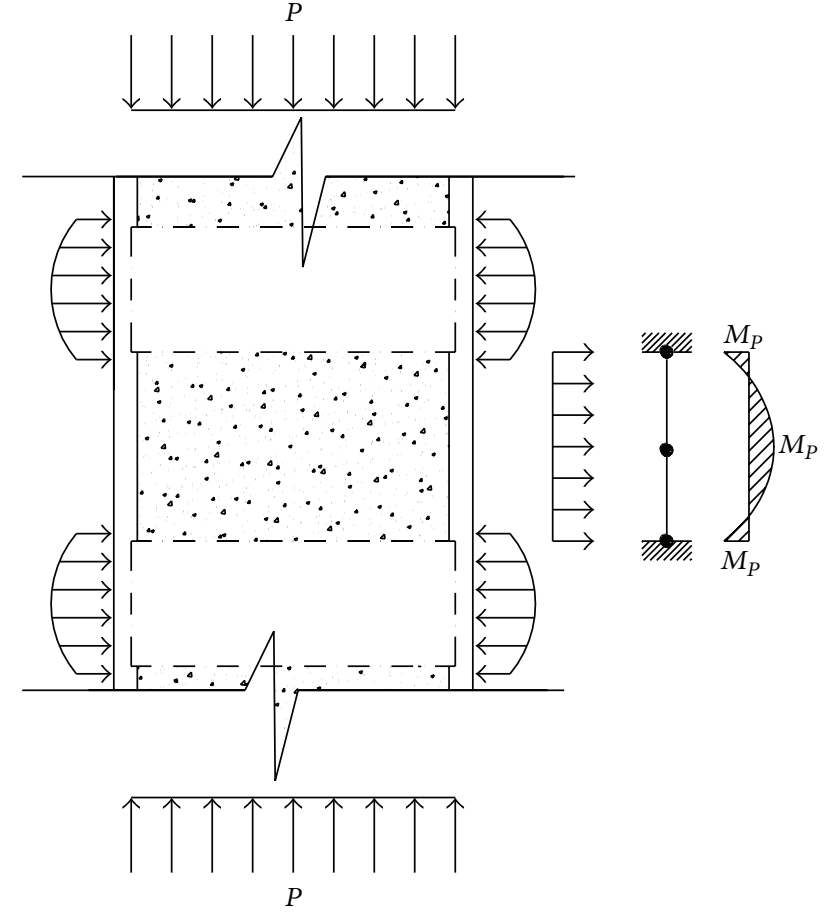

FIGURE 11: Crushing failure of concrete.

spacing showed a more beneficial effect on the ductility response when compared to the column confined with one and two layers. The displacement ductility index of column NC-20-3 was increased by $26.41 \%$ compared to the reference column. However, column NC-40-3 showed only a $4.71 \%$ enhancement compared to the reference column. From this, it is concluded that increasing to a high spacing between the CFRP strips results in the wrapping having only a superficial effect on the ductility behaviour of the column. It is suggested that the CFRP material with smaller spacing can be used as a strengthening material to improve the performance of the $\mathrm{RC}$ column without affecting the ductility performance.

3.4. Ultimate Strength and Stiffness. The measured ultimate strength of all strengthened columns and their enhancements in strength compared to the reference column are presented in Table 1. Figure 18 clearly shows that the external confinement provided by the CFRP strips composites enhances the strength capacity of the RC column; however, the enhancement was only high for the columns confined with more layers and smaller spacing, which is evident from Figure 18. For the column confined with $20 \mathrm{~mm}$ spacing, in comparison with the reference column, the column strengthened with one layer of CFRP strips did not show any significant increase in strength, and furthermore it has enhanced its strength by only $34.12 \%$ compared to that of the reference column. However, the columns NC-20-2 and NC-20-3 increased their strength capacity by $58.73 \%$ and $99.20 \%$, respectively, compared to that of the reference column. The increase in the composite plate thickness provides more confinement pressure during Poisson's effect of the concrete and keeps

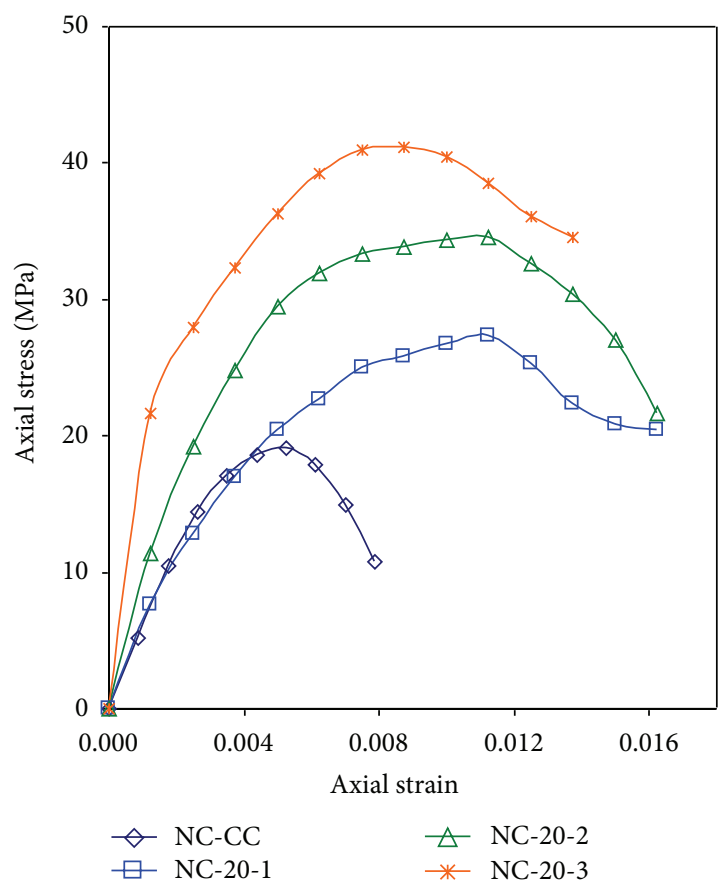

FIGURE 12: Axial stress-strain behaviour of columns confined with $20 \mathrm{~mm}$ spacing, comparison.

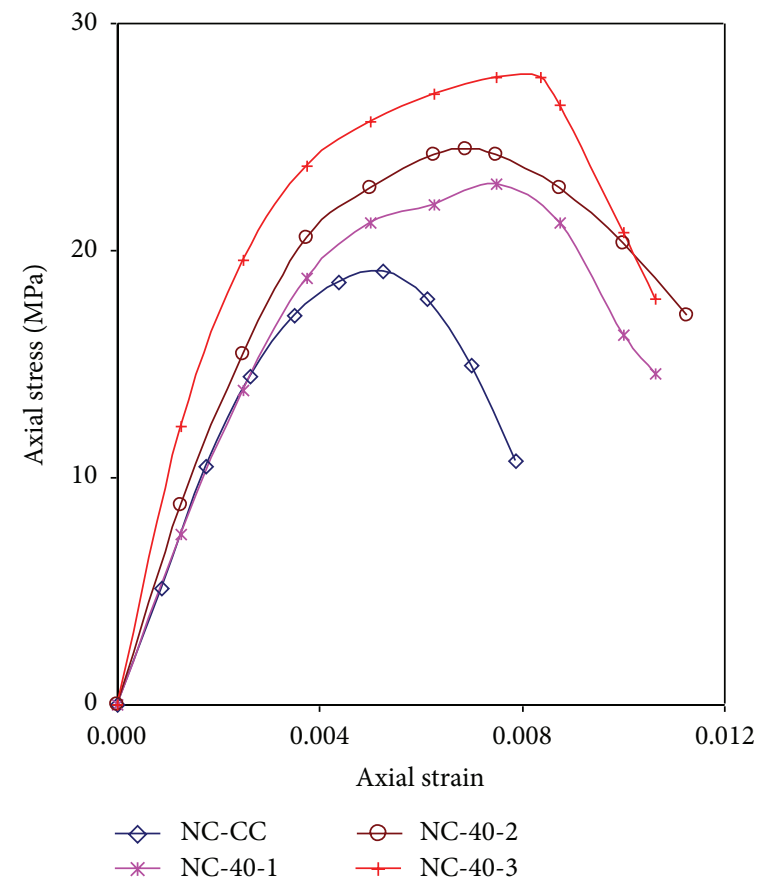

FIGURE 13: Axial stress-strain behaviour of columns confined with $40 \mathrm{~mm}$ spacing, comparison.

the concrete in a state of three-dimensional stress, and as a result the compressive strength and stiffness of the concrete are increased. This mechanism led to an increase in the strength capacity of the column. This tendency exposed the fact that having more than one layer of CFRP strips provides a significant improvement in the strength capacity of 


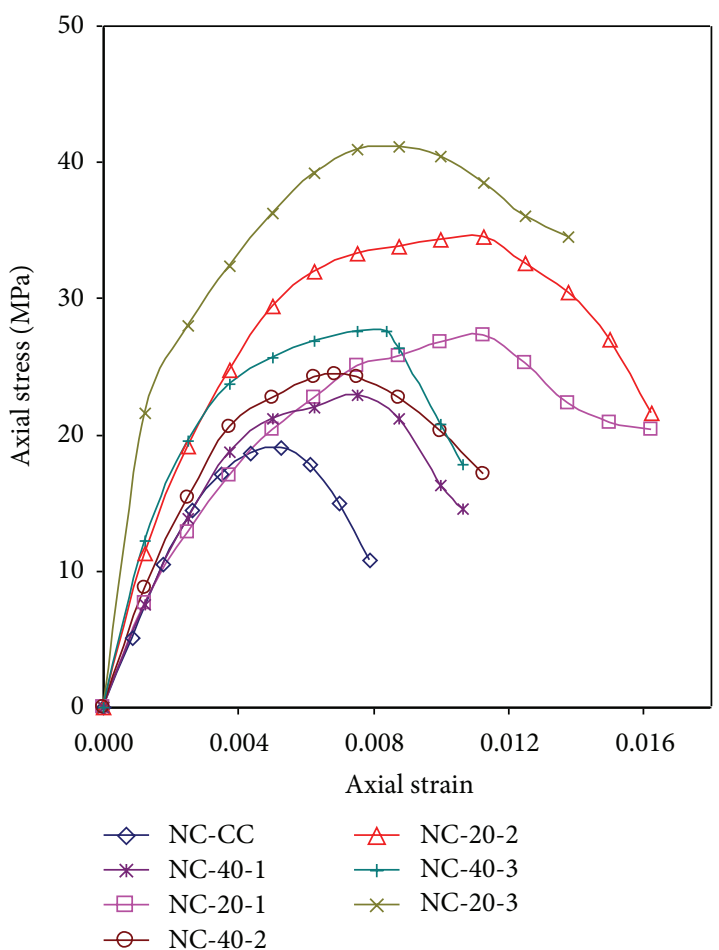

FIGURE 14: Axial stress-strain behaviour of all columns, comparison.

the column. It is interesting to note that while the strength capacity of the columns was increased with the increases in the number of layers, the enhancement was not proportional, as is shown in Figure 19. As was discussed earlier, this could be attributed to the crushing failure of resin between the CFRP composite strips. In contrast, the enhancement in the strength of the column confined with $40 \mathrm{~mm}$ spacing was not significant (see Figure 18), and the column confined with one and two layers showed a strength capacity nearly equal to that of the reference column. The columns NC-401, NC-40-2, and NC-40-3 showed a strength capacity that was enhanced by $3.57 \%, 23.02 \%$, and $34.74 \%$, respectively, when compared to the reference column. These outcomes lead us to the conclusion that the increase in strength capacity can be achieved only with a smaller spacing. The column's capacity to provide a restraint effect against deformation during loading can be referred to as stiffness of the column [65]. The stiffness of the columns was evaluated from the obtained load deformation value, and the values are listed in Table 1 and presented in Figure 20. All the columns showed higher stiffness during initial loading; however, the stiffness of the columns started to decrease with the increase in the applied load. The column confined with CFRP strips had high stiffness throughout the entire loading compared to the reference column, due to the prevention of Poisson's effect of concrete through the additional confining pressure provided by the CFRP strips. However, increasing the effective spacing between the strips decreased the stiffness of the column when compared to the column confined with smaller spacing, as is shown in Figure 20. In comparison to the column with three

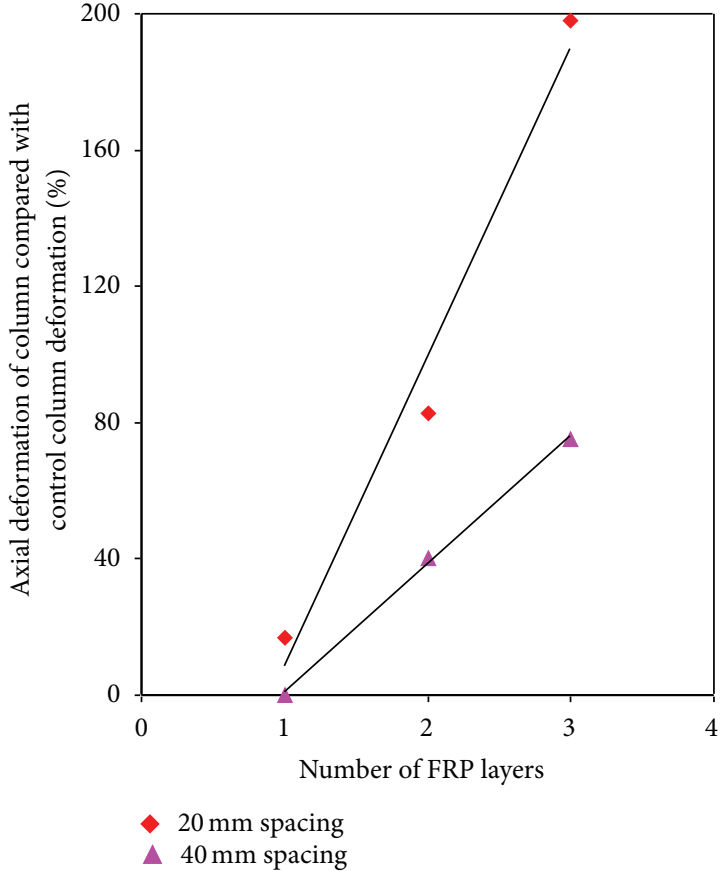

FIGURE 15: Relation between axial deformation control and number of CFRP layers.

layers in $40 \mathrm{~mm}$ spacing (NC-40-3), the column NC-20-3 showed an increase in stiffness of $68.98 \%$, and this increase in strength is high.

The strength enhancement ratios found in some of the previous studies performed on RC columns externally strengthened by full wrapping are summarized in Table 3 and are compared with this present study in Figure 21. Table 3 covers the geometric properties of the specimen (size and height): strength value of unconfined column $\left(f_{\text {ucon }}\right)$, confinement type, type of fibre, number of layers $(n)$, and strength value of FRP confined column $\left(f_{\mathrm{cc}}\right)$. From Table 3 and Figure 21, it can be understood that the strength enhancement ratio of this present study is very close to the $\mathrm{RC}$ column confined by full wrapping, and thus it can be concluded that the confinement provided by the FRP strips is relatively equal to the confinement provided by the full wrapping. From the test results, it is suggested that CFRP strips with the spacing of $20 \mathrm{~mm}$ can be used to improve the strength capacity of the RC column. In addition, the CFRP strips strengthening technique provides a cost-effective solution in place of the column confined with full wrapping.

\section{Evaluating the Ultimate Strength of FRP Confined RC Column Based on Existing Models}

Over the past several decades, various researchers suggested many expressions to evaluate the strength capacity of the FRP confined column. However, expression (2) proposed by Richart et al. [66] is widely accepted by many researchers. 


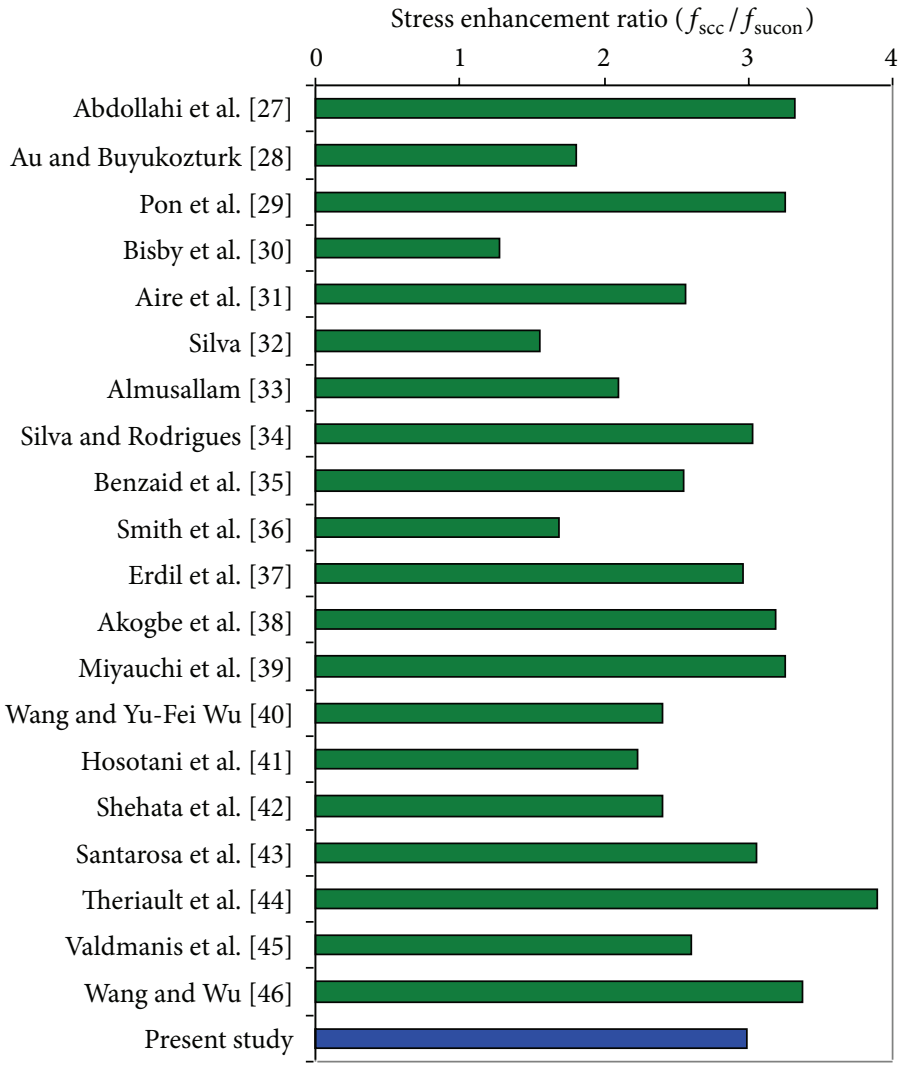

FIGURE 16: Stress enhancement ratio of present and previous studies, comparison.

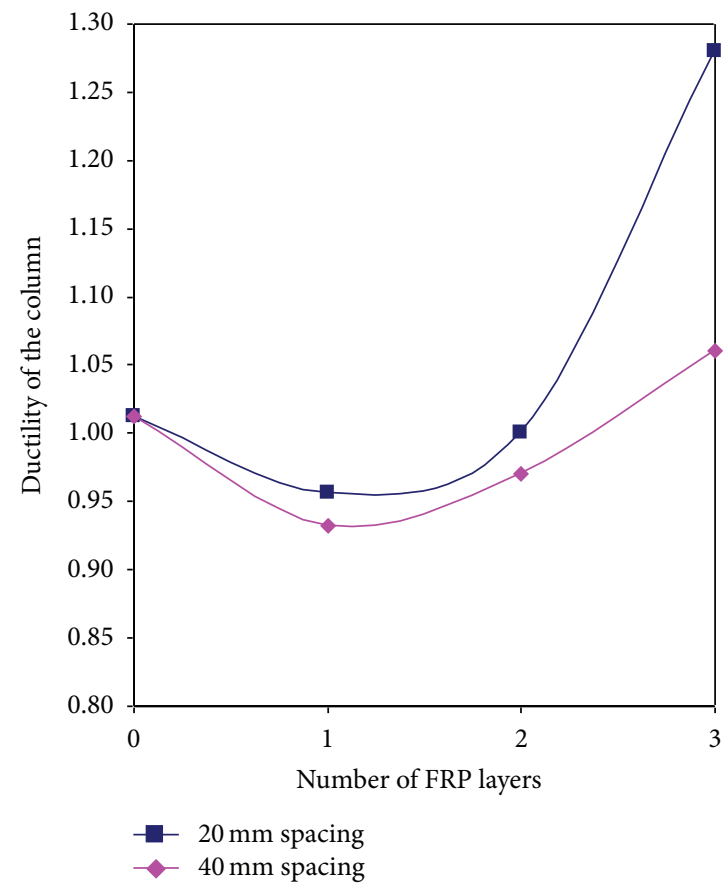

FIGURE 17: Displacement ductility behaviour of all columns, comparison. 


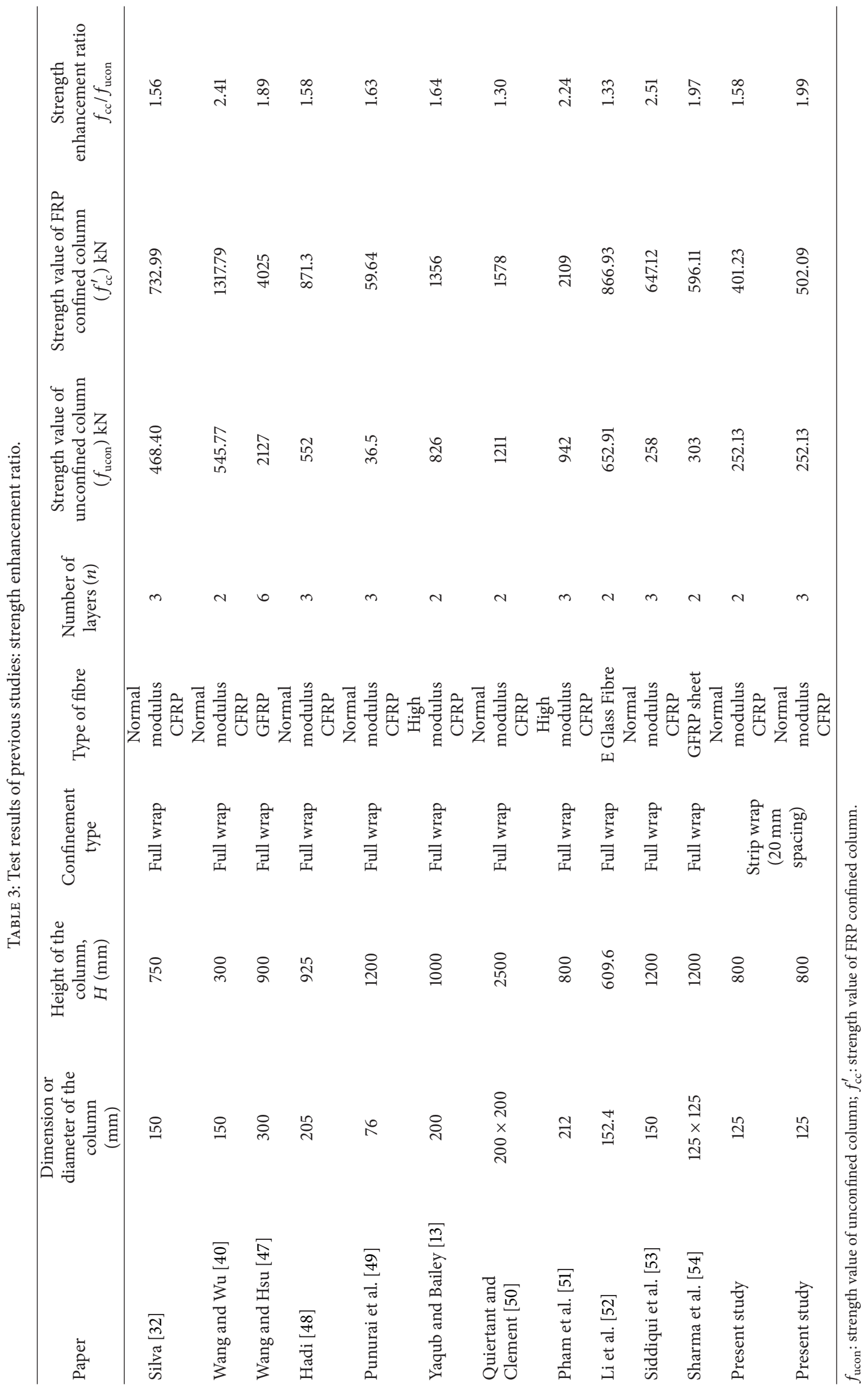




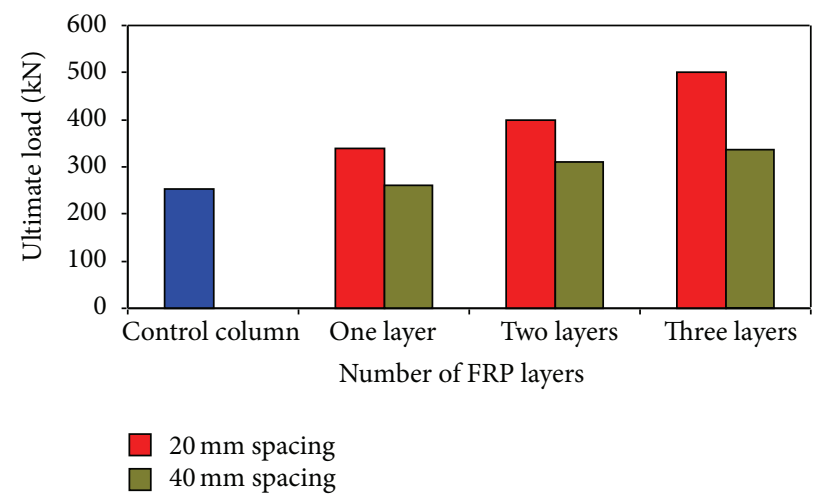

FIGURE 18: Ultimate axial strength of all strengthened columns, comparison.

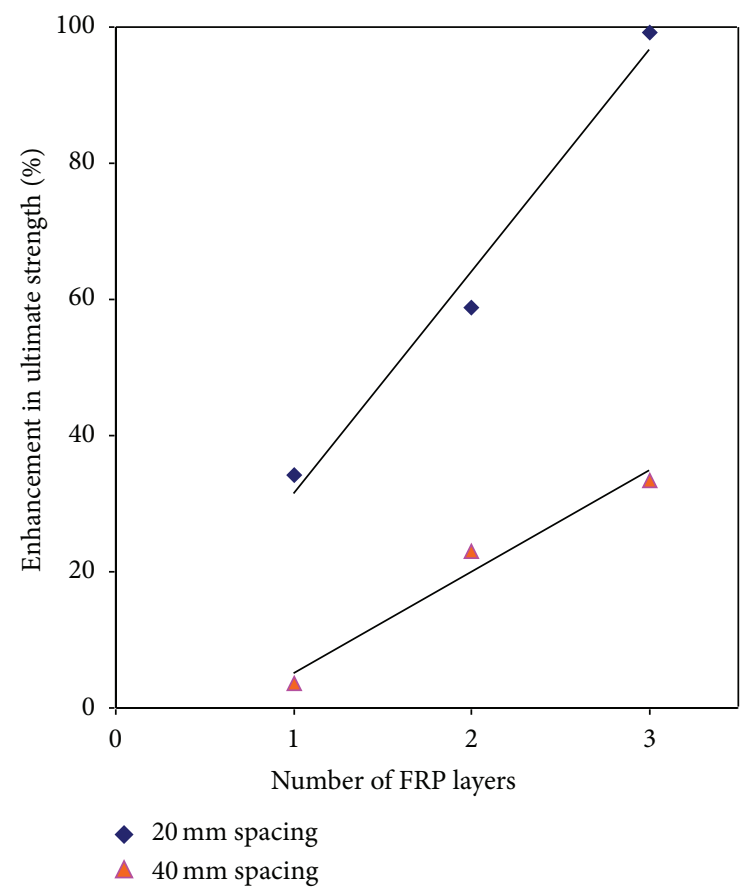

FIGURE 19: Relation between enhancement in ultimate strength and number of CFRP layers.

It is a simple equation, and the confinement coefficient can be adjusted based on the type of fibre used:

$$
\frac{f_{\mathrm{cc}}}{f_{\mathrm{ucon}}}=1+k \frac{f_{\mathrm{lc}}}{f_{\mathrm{ucon}}}
$$

where $f_{\mathrm{cc}}$ is the compressive strength of FRP confined column; $f_{\text {lc }}$ is lateral confinement pressure exerted by the FRP composites; and $f_{\text {ucon }}$ and $k$ are unconfined compressive strength of the column and effective confinement coefficient, respectively. Based on the model proposed by Siddiqui et al. [53], numerous expressions were proposed in previous research, and a summary of some of the expressions found in the literature $[14,39,58-62,67,68]$, for estimating the strength capacity of the FRP confined column, is considered in this study. From (2), it can be understood that the strength capacity of the FRP confined column depends upon the confinement ratio $\left(f_{\mathrm{lc}} / f_{\text {ucon }}\right)$ in addition to confinement pressure $\left(f_{\mathrm{lc}}\right)$ exerted by the FRP composite affecting the strength performance of the FRP confined concrete. Among the few models $[14,39,58-62,67,68]$, the model proposed by Miyauchi et al. [39] was considered in this study to evaluate the ultimate strength capacity of the FRP confined RC column, since the models proposed by various studies showed a lower prediction, which is shown in Figure 22; in addition, the percentage of difference of the studies was also very high (see Table 4 ). The modes proposed by Miyauchi et al. [39] are as follows:

$$
f_{\mathrm{cc}}=f_{\mathrm{ucon}}\left[1+3.5\left(\frac{f_{\mathrm{lc}}}{f_{\mathrm{ucon}}}\right)\right] \text {. }
$$

When the column is subjected to uniform pressure on the top of the surface of the column, the concrete starts to expand laterally due to Poisson's effect on the concrete, while the FRP strips in the outer limits prevent Poisson's effect by providing confinement pressure as they are subjected to tension in the hoop direction. As the axial stress increases, the corresponding lateral strain increases and the FRP develops its maximum tensile hoop stress, which is equal to the ultimate tensile strength of CFRP $\left(f_{\text {frp }}\right)$ balanced by the lateral pressure $\left(f_{\mathrm{lc}}\right)$ as shown in Figure 23. By considering the equilibrium, (4) [1] can be derived to find the lateral confinement pressure $\left(f_{\mathrm{lc}}\right)$ provided by the FRP composites:

$$
f_{\mathrm{lc}}=\frac{\rho_{\text {frp }} f_{\text {frp }}}{2},
$$

where $f_{\mathrm{lc}}$ is the lateral confinement pressure exerted by the CFRP strips; $f_{\text {frp }}$ is the tensile strength of FRP in the hoop direction; $\rho_{\text {frp }}$ is the FRP volumetric ratio to concrete for the column wrapped with CFRP strips (Figure 1) and can be determined by the following equation:

$$
\rho_{\text {frp }}=\frac{8 t_{\text {frp }} b_{\text {frp }}}{D\left(b_{\text {frp }}+s_{\text {frp }}\right)},
$$




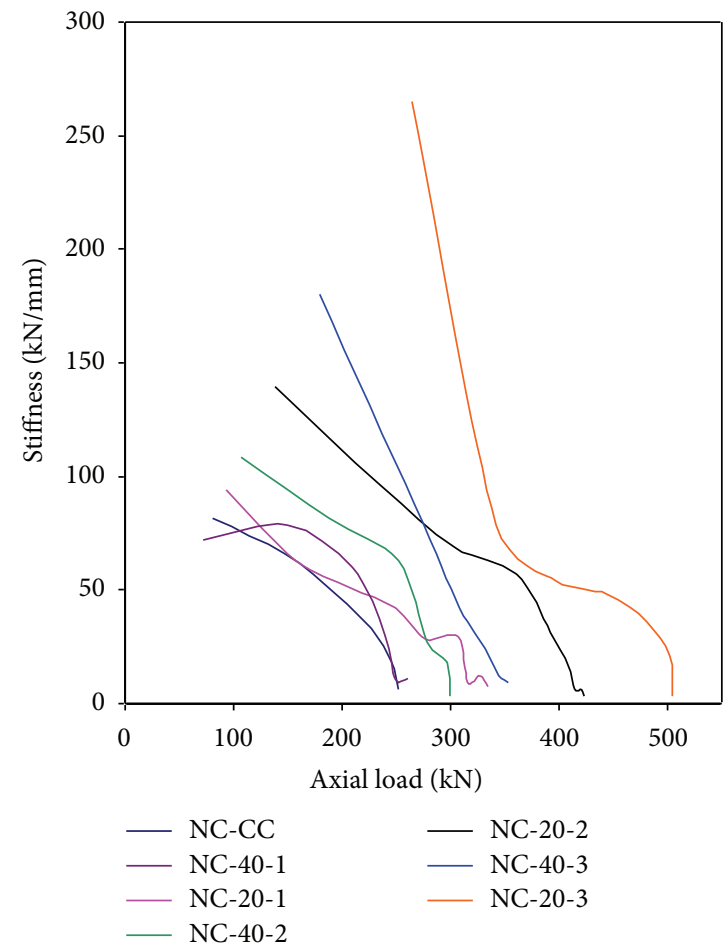

FIGURE 20: Stiffness value of all strengthened columns, comparison.

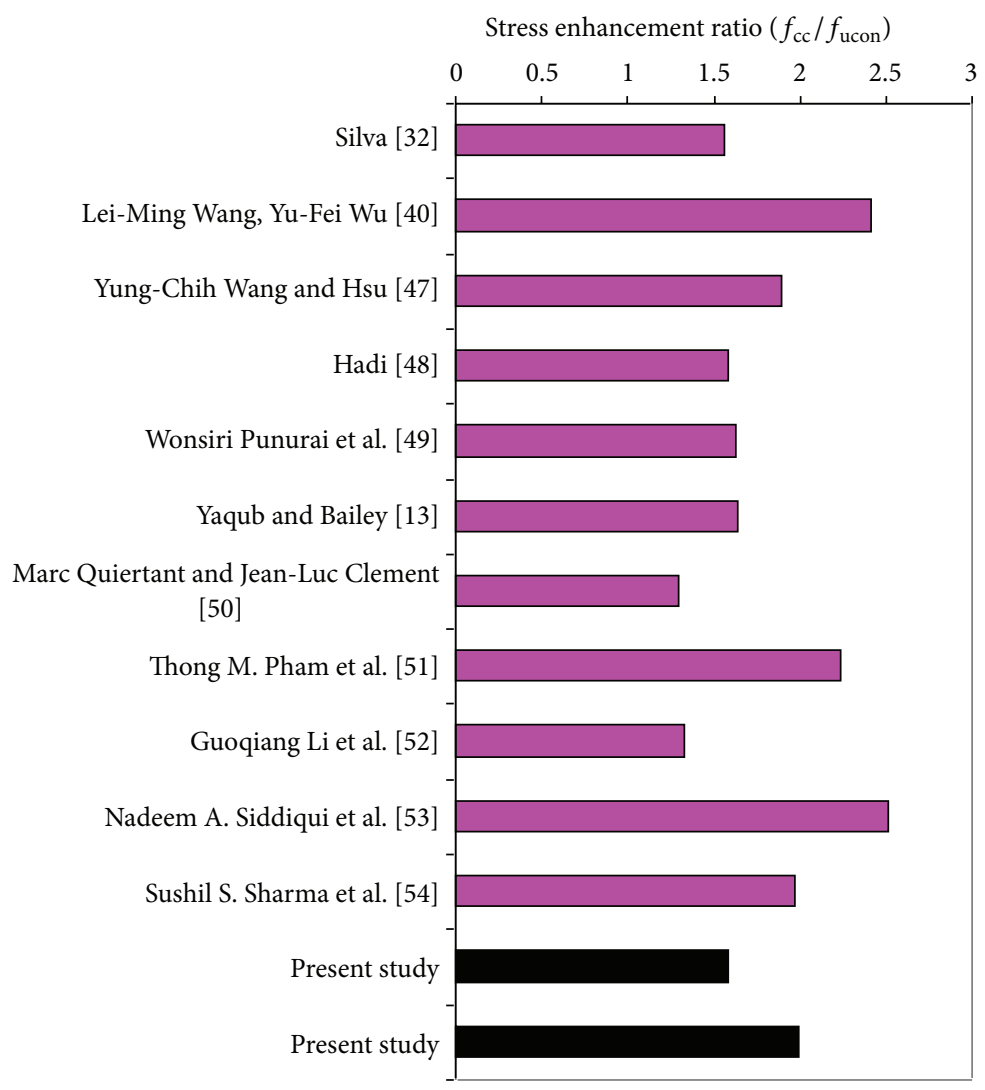

FIGURE 21: Strength enhancement ratio of present and previous studies, comparison. 
TABle 4: Percentage of error (PE) of some models used to predict the peak axial strength of concrete columns.

\begin{tabular}{lccccccccc}
\hline $\begin{array}{l}\text { Designation } \\
\text { of columns }\end{array}$ & $\begin{array}{c}\text { Wu et al. } \\
{[14]}\end{array}$ & $\begin{array}{c}\text { Miyauchi } \\
\text { et al. [39] }\end{array}$ & $\begin{array}{c}\text { Benzaid } \\
\text { and } \\
\text { Mesbah } \\
{[58]}\end{array}$ & $\begin{array}{c}\text { Shehata et } \\
\text { al. [59] }\end{array}$ & $\begin{array}{c}\text { Tamuzs et } \\
\text { al. [67] }\end{array}$ & $\begin{array}{c}\text { Karbhari } \\
\text { and Gao } \\
{[60]}\end{array}$ & $\begin{array}{c}\text { Youssef et } \\
\text { al. [68] }\end{array}$ & $\begin{array}{c}\text { Toutanji } \\
\text { [61] }\end{array}$ & $\begin{array}{c}\text { Wei and } \\
\text { Wu [62] }\end{array}$ \\
\hline NC-20-1 & 28.52 & 8.48 & 14.33 & 15.75 & 5.09 & 10.92 & 14.54 & -0.12 & 12.88 \\
NC-20-2 & 26.69 & 8.33 & 20.19 & 20.62 & 2.60 & 14.58 & 18.57 & -1.93 & 16.63 \\
NC-20-3 & 31.75 & 15.54 & 30.97 & 30.22 & 8.69 & 24.38 & 27.77 & 6.02 & 26.04 \\
NC-40-1 & 11.94 & -13.64 & -8.21 & -6.31 & -17.05 & -11.66 & -7.54 & -23.29 & -9.40 \\
NC-40-2 & 12.72 & -10.06 & 1.15 & 2.27 & -15.81 & -4.54 & 0.22 & -21.86 & -2.04 \\
NC-40-3 & 8.57 & -13.80 & 3.09 & 3.11 & -21.69 & -4.59 & 0.29 & -26.70 & -2.11 \\
\hline
\end{tabular}

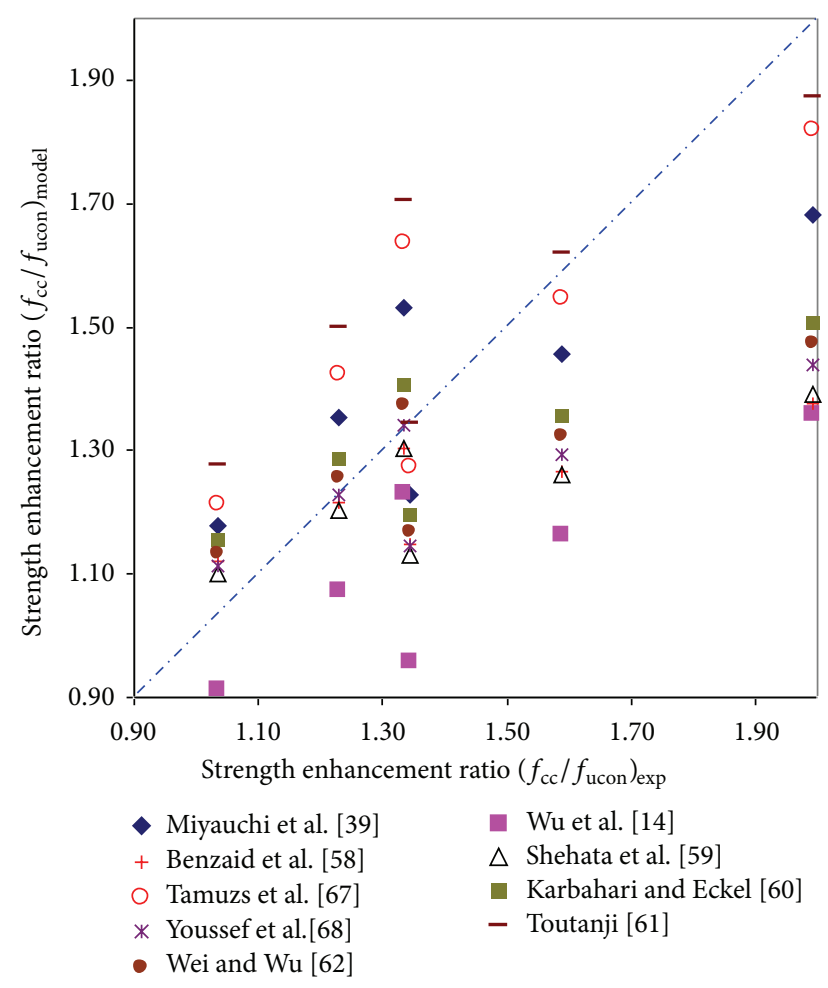

FIGURE 22: Correlation between theoretical strength enhancement ratio using various existing models and experimental strength enhancement ratio.

where $b_{\text {frp }}$ and $t_{\text {frp }}$ are the width of CFRP strips and thickness of the FRP confinement, respectively; $D$ and $s_{\text {frp }}$ are the diameter of the column and clear spacing between the CFRP strips. The load carrying capacity of the FRP confined columns was evaluated through (3) [39] and listed in Table 1. The correlation between the measured and theoretical strengths of the FRP confined column is quite strong, as shown in Figure 24.

\section{Conclusion}

The effectiveness and economic advantages of using CFRP composite strips to strengthen RC columns were investigated.

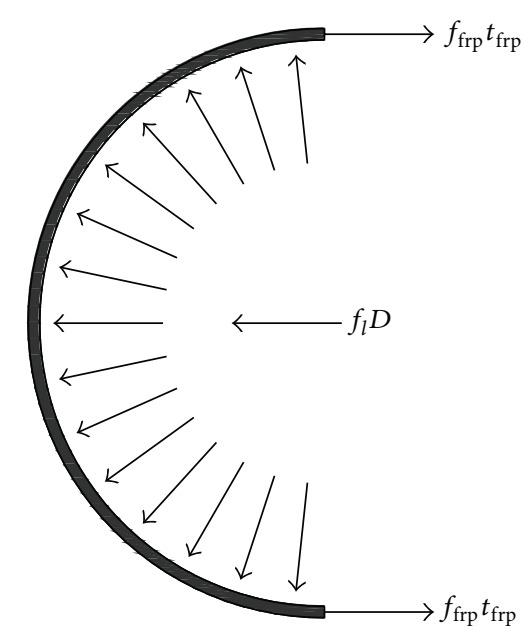

FIGURE 23: Confinement pressure provided by the CFRP strips CFRP layers.

The parameters used included effective spacing between the CFRP strips and number of FRP layers. Based on the test results obtained, the following conclusions can be drawn:

(1) Columns confined with smaller spacing $(20 \mathrm{~mm})$ showed a greater restraint of Poisson's effect on the concrete, and this enhanced the strength capacity of the column significantly. In comparison with the reference column, the columns with $20 \mathrm{~mm}$ spacing showed a restraint of Poisson's effect and a strength capacity that were increased by $197.87 \%$ and $99.20 \%$, respectively. An increase in the number of layers improved the performance of the column further; however, this improvement was not linear. In addition, the presence of CFRP layers increased the ductility performance of the column; in particular, the columns confined with three layers showed a more beneficial effect.

(2) The increase in the spacing between the CFRP strips from $20 \mathrm{~mm}$ to $40 \mathrm{~mm}$ showed excessively inferior effects in terms of restraining in axial deformation, ductility performance, and strength capacity of the column when compared to the column confined with 


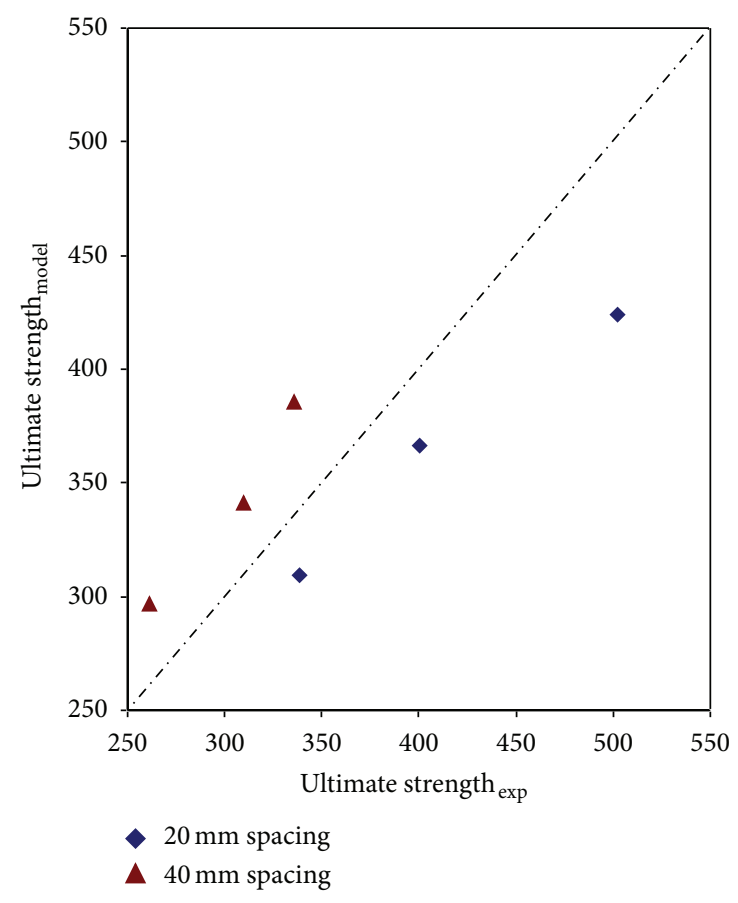

Figure 24: Correlation between experimental and theoretical strength enhancement ratios.

$20 \mathrm{~mm}$ spacing. All the columns failed by crushing concrete alone without any rupture of CFRP composites. In addition, the embodied energy that exists in the CFRP strips was not effectively utilized due to the above mentioned effect. The columns showed an enhancement in the strength capacity of up to $33.33 \%$ when compared to the reference column.

(3) The ultimate strength capacity of the strengthened columns predicted using Miyauchi et al's [39] expression fairly agreed with the experimental results.

(4) The stress and strength enhancement ratio of this present study is very close to the findings related to RC columns confined by full wrapping, and it is suggested that the CFRP strips with smaller spacing $(20 \mathrm{~mm})$ can be used to improve the strength capacity of the RC column. In addition, this CFRP strip strengthening technique provides a solution that is $40 \%$ more costeffective than confining a column with full wrapping.

\section{Notations}

$\Delta_{u}: \quad$ Ultimate axial deformation

$\mu_{\Delta}: \quad$ Ductility index of the column

$\Delta: \quad$ Axial deformation of the column

$\Delta_{y}: \quad$ Deformation at the respective yield load of the column

$f_{\text {ucon }}$ : Strength value of unconfined column

$n$ : Number of layers

$f_{c c}$ : Strength value of FRP confined column

$f_{\mathrm{lc}}$ : Lateral confinement pressure exerted by the FRP composites $k$ : $\quad$ Effective confinement coefficient

$f_{\text {frp }}$ : Ultimate tensile strength of CFRP

$\rho_{\text {frp }}$ : FRP volumetric ratio

$b_{\text {frp }}:$ Width of CFRP strips

$t_{\text {frp }}$ : Thickness of the FRP confinement

$D$ : Diameter of the column

$s_{\text {frp }}$ : Clear spacing between the CFRP strips.

\section{Conflict of Interests}

The authors declare that there is no conflict of interests regarding the publication of this paper.

\section{References}

[1] L. Lam and J. G. Teng, "Strength models for fiber-reinforced plastic-confined concrete," Journal of Structural Engineering, vol. 128, no. 5, pp. 612-623, 2002.

[2] Y.-F. Wu, T. Liu, and D. J. Oehlers, "Fundamental principles that govern retrofitting of reinforced concrete columns by steel and FRP jacketing," Advances in Structural Engineering, vol. 9, no. 4, pp. 507-532, 2006.

[3] H. Fukuyama and S. Sugano, "Japanese seismic rehabilitation of concrete buildings after the Hyogoken-Nanbu Earthquake," Cement and Concrete Composites, vol. 22, no. 1, pp. 59-79, 2000.

[4] R. K. L. Su and L. Wang, "Axial strengthening of preloaded rectangular concrete columns by precambered steel plates," Engineering Structures, vol. 38, pp. 42-52, 2012.

[5] K. Soudki and T. Alkhrdaji, "Guide for the design and construction of externally bonded FRP systems for strengthening concrete structures," ACI 440.2 R-02, 2005.

[6] S. Pessiki, K. A. Harries, J. T. Kestner, R. Sause, and J. M. Ricles, "Axial behavior of reinforced concrete columns confined with FRP jackets," Journal of Composites for Construction, vol. 5, no. 4, pp. 237-245, 2001.

[7] Y. Xiao and H. Wu, "Compressive behavior of concrete confined by carbon fiber composite jackets," Journal of Materials in Civil Engineering, vol. 12, no. 2, pp. 139-146, 2000.

[8] K. Maruyama, H. Nakai, F. Katsuki, and T. Shimomura, "Improvement of shear and ductility of reinforced concrete columns by wrapping of continuous fiber-reinforced polymer sheet," Advanced Composite Materials, vol. 10, no. 2-3, pp. 119126, 2001.

[9] H. Toutanji and Y. Deng, "Performance of concrete columns strengthened with fiber reinforced polymer composite sheets," Advanced Composite Materials, vol. 10, no. 2-3, pp. 159-168, 2001.

[10] O. Chaallal, M. Shahawy, and M. Hassan, "Performance of axially loaded short rectangular columns strengthened with carbon fiber-reinforced polymer wrapping," Journal of Composites for Construction, vol. 7, no. 3, pp. 200-208, 2003.

[11] A. Mukherjee, T. E. Boothby, C. E. Bakis, M. V. Joshi, and S. R. Maitra, "Mechanical behavior of fiber-reinforced polymerwrapped concrete columns-complicating effects," Journal of Composites for Construction, vol. 8, no. 2, pp. 97-103, 2004.

[12] M. K. Zaki, "Investigation of FRP strengthened circular columns under biaxial bending," Engineering Structures, vol. 33, no. 5, pp. 1666-1679, 2011. 
[13] M. Yaqub and C. G. Bailey, "Repair of fire damaged circular reinforced concrete columns with FRP composites," Construction and Building Materials, vol. 25, no. 1, pp. 359-370, 2011.

[14] G. Wu, Z. T. Lü, and Z. S. Wu, "Strength and ductility of concrete cylinders confined with FRP composites," Construction and Building Materials, vol. 20, no. 3, pp. 134-148, 2006.

[15] T. W. Park, U. J. Na, L. Chung, and M. Q. Feng, "Compressive behavior of concrete cylinders confined by narrow strips of CFRP with spacing," Composites Part B: Engineering, vol. 39, no. 7-8, pp. 1093-1103, 2008.

[16] H. Bouchelaghem, A. Bezazi, and F. Scarpa, "Compressive behaviour of concrete cylindrical FRP-confined columns subjected to a new sequential loading technique," Composites Part B: Engineering, vol. 42, no. 7, pp. 1987-1993, 2011.

[17] J. L. Pan, T. Xu, and Z. J. Hu, "Experimental investigation of load carrying capacity of the slender reinforced concrete columns wrapped with FRP," Construction and Building Materials, vol. 21, no. 11, pp. 1991-1996, 2007.

[18] Z. S. Wu, K. Iwashita, K. Hayashi, T. Higuchi, S. Murakami, and Y. Koseki, "Strengthening prestressed-concrete girders with externally prestressed PBO fiber reinforced polymer sheets," Journal of Reinforced Plastics \& Composites, vol. 22, no. 14, pp. 1269-1286, 2003.

[19] S. E. Mouring, O. Barton Jr., and D. K. Simmons, "Reinforced concrete beams externally retrofitted with advanced composites," Advanced Composite Materials, vol. 10, no. 2-3, pp. 139-146, 2001.

[20] N. Attari, S. Amziane, and M. Chemrouk, "Efficiency of beamcolumn joint strengthened by FRP laminates," Advanced Composite Materials, vol. 19, no. 2, pp. 171-183, 2010.

[21] Z. Y. Sun, G. Wu, Z. S. Wu, and Y. B. Luo, "Flexural strengthening of concrete beams with near-surface mounted steelfiber-reinforced polymer composite bars," Journal of Reinforced Plastics and Composites, vol. 30, no. 18, pp. 1529-1537, 2011.

[22] T. Sen and H. N. J. Reddy, "Pretreatment of woven jute FRP composite and its use in strengthening of reinforced concrete beams in flexure," Advances in Materials Science and Engineering, vol. 2013, Article ID 128158, 15 pages, 2013.

[23] B. Hu, J.-G. Wang, and G.-Q. Li, "Numerical simulation and strength models of FRP-wrapped reinforced concrete columns under eccentric loading," Construction and Building Materials, vol. 25, no. 5, pp. 2751-2763, 2011.

[24] B. Csuka and L. P. Kollár, "Analysis of FRP confined columns under eccentric loading," Composite Structures, vol. 94, no. 3, pp. 1106-1116, 2012.

[25] G. P. Lignola, F. Nardone, A. Prota, and G. Manfredi, "Analytical model for the effective strain in FRP-wrapped circular RC columns," Composites Part B: Engineering, vol. 43, no. 8, pp. 3208-3218, 2012.

[26] T. Jiang and J. G. Teng, "Theoretical model for slender FRPconfined circular RC columns," Construction and Building Materials, vol. 32, pp. 66-76, 2012.

[27] B. Abdollahi, M. Bakhshi, M. Motavalli, and M. Shekarchi, "Experimental modeling of GFRP confined concrete cylinders subjected to axial loads," in Proceedings of the 8th International Symposium on Fiber Reinforced Polymer Reinforcement for Concrete Structures, Patras, Greece, 2007.

[28] C. Au and O. Buyukozturk, "Effect of fiber orientation and ply mix on fiber reinforced polymer-confined concrete," Journal of Composites for Construction, vol. 9, no. 5, pp. 397-407, 2005.
[29] T. H. Pon, Y. F. Li, B. J. Shih, M. S. Han, G. D. Chu, and Y. J. Chiu, "Experiments of scale effects on the strength of FRP reinforced concrete," in Proceedings of the 4th National Conference on Structural Engineering, Taipei, Taiwan, 1998.

[30] L. Bisby, W. A. Take, and A. Caspary, "Quantifying strain variation FRP confined using digital image correlation: proofof-concept and initial results," in Proceedings of the Asia-Pacific Conference on FRP in Structures, 2007.

[31] C. Aire, R. Gettu, J. R. Casas, S. Marques, and D. Marques, "Concrete laterally confined with fibre-reinforced polymers (FRP): experimental study and theoretical model," Materiales de Construccion, vol. 60, no. 297, pp. 19-31, 2010.

[32] M. A. G. Silva, "Behavior of square and circular columns strengthened with aramidic or carbon fibers," Construction and Building Materials, vol. 25, no. 8, pp. 3222-3228, 2011.

[33] T. H. Almusallam, "Behavior of normal and high-strength concrete cylinders confined with E-glass/epoxy composite laminates," Composites Part B: Engineering, vol. 38, no. 5-6, pp. 629639, 2007.

[34] M. A. G. Silva and C. C. Rodriguez, "Size and relative stiffness effects on compressive failure of concrete columns wrapped with glass FRP," Journal of Materials in Civil Engineering, vol. 18, no. 3, pp. 334-342, 2006.

[35] R. Benzaid, H. Mesbah, and N. Chikh, "FRP-confined concrete cylinders: axial compression experiments and strength model," Journal of Reinforced Plastics and Composites, vol. 29, no. 16, pp. 2469-2488, 2010.

[36] S. T. Smith, S. J. Kim, and H. Zhang, "Behavior and effectiveness of FRP wrap in the confinement of large concrete cylinders," Journal of Composites for Construction, vol. 14, no. 5, pp. 573$582,2010$.

[37] B. Erdil, U. Akyuz, and I. O. Yaman, "Mechanical behavior of CFRP confined low strength concretes subjected to simultaneous heating-cooling cycles and sustained loading," Materials and Structures, vol. 45, no. 1-2, pp. 223-233, 2012.

[38] R. Akogbe, M. Liang, and Z. Wu, "Size effect of axial compressive strength of CFRP confined concrete cylinders," International Journal of Concrete Structures and Materials, vol. 5, no. 1, pp. 49-55, 2011.

[39] K. Miyauchi, S. Nishibayashi, and S. Inoue, "Estimation of strengthening effects with carbon fiber sheet for concrete column," in Proceedings of the 3rd International Symposium on Non-Metallic Reinforcement for Concrete Structures, Sapporo, Japan, 1997.

[40] L.-M. Wang and Y.-F. Wu, "Effect of corner radius on the performance of CFRP-confined square concrete columns: test," Engineering Structures, vol. 30, no. 2, pp. 493-505, 2008.

[41] K. Hosotani, K. Kawashima, and J. Hoshikuma, "A model for confinement effect for concrete cylinders confined by carbon fiber sheets," in Proceedings of the NCEER-INCEDE Workshop on Earthquake Engineering Frontiers of Transportation Facilities, State University of New York, Buffalo, NY, USA, 1997.

[42] I. A. E. M. Shehata, L. A. V. Carneiro, and L. C. D. Shehata, "Strength of confined short concrete columns," in Proceedings of the 8th International Symposium on Fiber Reinforced Polymer Reinforcement for Concrete Structures, Patras, Greece, 2007.

[43] D. Santarosa, A. C. Filho, A. J. Beber, and J. L. Campagnolo, "Concrete columns confined with CFRP sheets," in Proceedings of the International Conference of FRP Composites in Civil Engineering, Hong Kong, China, 2001.

[44] M. Thériault, K. W. Neale, and S. Claude, "Fiber-reinforced polymer-confined circular concrete columns: investigation of 
size and slenderness effects," Journal of Composites for Construction, vol. 8, no. 4, pp. 323-331, 2004.

[45] V. Valdmanis, L. De Lorenzis, T. Rousakis, and R. Tepfers, "Behaviour and capacity of CFRP-confined concrete cylinders subjected to monotonic and cyclic axial compressive load," Structural Concrete, vol. 8, no. 4, pp. 187-200, 2007.

[46] Y.-F. Wang and H.-L. Wu, "Size effect of concrete short columns confined with aramid FRP jackets," Journal of Composites for Construction, vol. 15, no. 4, pp. 535-544, 2011.

[47] Y.-C. Wang and K. Hsu, "Design of FRP-wrapped reinforced concrete columns for enhancing axial load carrying capacity," Composite Structures, vol. 82, no. 1, pp. 132-139, 2008.

[48] M. N. S. Hadi, "Behaviour of FRP strengthened concrete columns under eccentric compression loading," Composite Structures, vol. 77, no. 1, pp. 92-96, 2007.

[49] W. Punurai, C.-T. T. Hsu, S. Punurai, and J. Chen, "Biaxially loaded RC slender columns strengthened by CFRP composite fabrics," Engineering Structures, vol. 46, pp. 311-321, 2013.

[50] M. Quiertant and J.-L. Clement, "Behavior of RC columns strengthened with different CFRP systems under eccentric loading," Construction and Building Materials, vol. 25, no. 2, pp. 452-460, 2011.

[51] T. M. Pham, L. V. Doan, and M. N. S. Hadi, "Strengthening square reinforced concrete columns by circularisation and FRP confinement," Construction and Building Materials, vol. 49, pp. 490-499, 2013.

[52] G. Li, S. Kidane, S.-S. Pang, J. E. Helms, and M. A. Stubblefield, "Investigation into FRP repaired RC columns," Composite Structures, vol. 62, no. 1, pp. 83-89, 2003.

[53] N. A. Siddiqui, S. H. Alsayed, Y. A. Al-Salloum, R. A. Iqbal, and H. Abbas, "Experimental investigation of slender circular RC columns strengthened with FRP composites," Construction and Building Materials, vol. 69, pp. 323-334, 2014.

[54] S. S. Sharma, U. V. Dave, and H. Solanki, "FRP wrapping for RC columns with varying corner radii," Procedia Engineering, vol. 51, pp. 220-229, 2013.

[55] A. M. Vasumathi, K. Rajkumar, and G. Ganesh Prabhu, "Compressive behaviour of RC column with fibre reinforced concrete confined by CFRP strips," Advances in Materials Science and Engineering, vol. 2014, Article ID 601915, 10 pages, 2014.

[56] IS 8112, Ordinary Portland Cement, 43 Grade-Specification, Bureau of Indian Standards, New Delhi, India, 2013.

[57] Bureau of Indian Standards, IS 2386 (Part 1). Methods of Test for Aggregates for Concrete: Part 1 Particle Size and Shape, Bureau of Indian Standards, New Delhi, India, 1963.

[58] R. Benzaid and H. Mesbah, "FRP-confined concrete cylinders: axial compression experiments and strength model," Journal of Reinforced Plastics and Composites, vol. 29, no. 16, pp. 24692488, 2010.

[59] I. A. E. M. Shehata, L. A. V. Carneiro, and L. C. D. Shehata, "Strength of short concrete columns confined with CFRP sheets," Materials and Structures, vol. 35, no. 1, pp. 50-58, 2002.

[60] V. M. Karbhari and Y. Gao, "Composite jacketed concrete under uniaxial compression-verification of simple design equations," Journal of Materials in Civil Engineering, vol. 9, no. 4, pp. 185193, 1997.

[61] H. A. Toutanji, "Stress-strain characteristics of concrete columns externally confined with advanced fiber composite sheets," ACI Materials Journal, vol. 96, no. 3, pp. 397-404, 1999.

[62] Y.-Y. Wei and Y.-F. Wu, "Unified stress-strain model of concrete for FRP-confined columns," Construction and Building Materials, vol. 26, no. 1, pp. 381-392, 2012.
[63] Bureau of Indian Standards, "Guidelines for concrete mix proportioning," IS 10262:2009, Bureau of Indian Standards, New Delhi, India, 2009.

[64] P. A. Calderón, J. M. Adam, S. Ivorra, F. J. Pallarés, and E. Giménez, "Design strength of axially loaded RC columns strengthened by steel caging," Materials and Design, vol. 30, no. 10, pp. 4069-4080, 2009.

[65] S. R. Gopal and P. D. Manoharan, "Experimental behaviour of eccentrically loaded slender circular hollow steel columns infilled with fibre reinforced concrete," Journal of Constructional Steel Research, vol. 62, no. 5, pp. 513-520, 2006.

[66] F. E. Richart, A. Brandtzaeg, and R. L. Brown, A Study of the Failure of Concrete under Combined Compressive Stresses, Engineering Experiment Station, University of Illinois, Urbana, Ill, USA, 1928.

[67] V. Tamuzs, R. Tepfers, E. Zile, and O. Ladnova, "Behavior of concrete cylinders confined by a carbon composite 3 . Deformability and the ultimate axial strain," Mechanics of Composite Materials, vol. 42, no. 4, pp. 303-314, 2006.

[68] M. N. Youssef, M. Q. Feng, and A. S. Mosallam, "Stress-strain model for concrete confined by FRP composites," Composites Part B: Engineering, vol. 38, no. 5-6, pp. 614-628, 2007. 

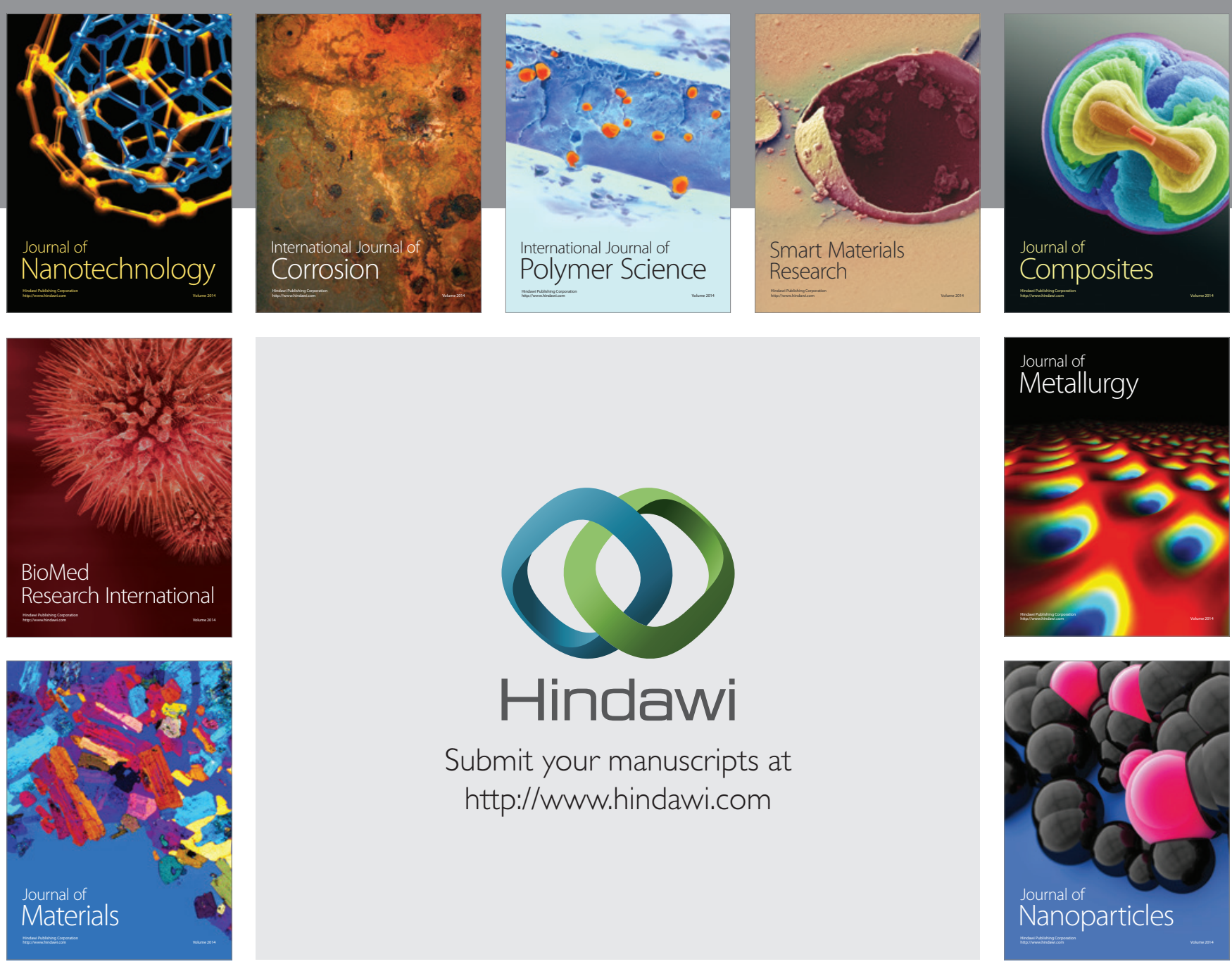

Submit your manuscripts at http://www.hindawi.com
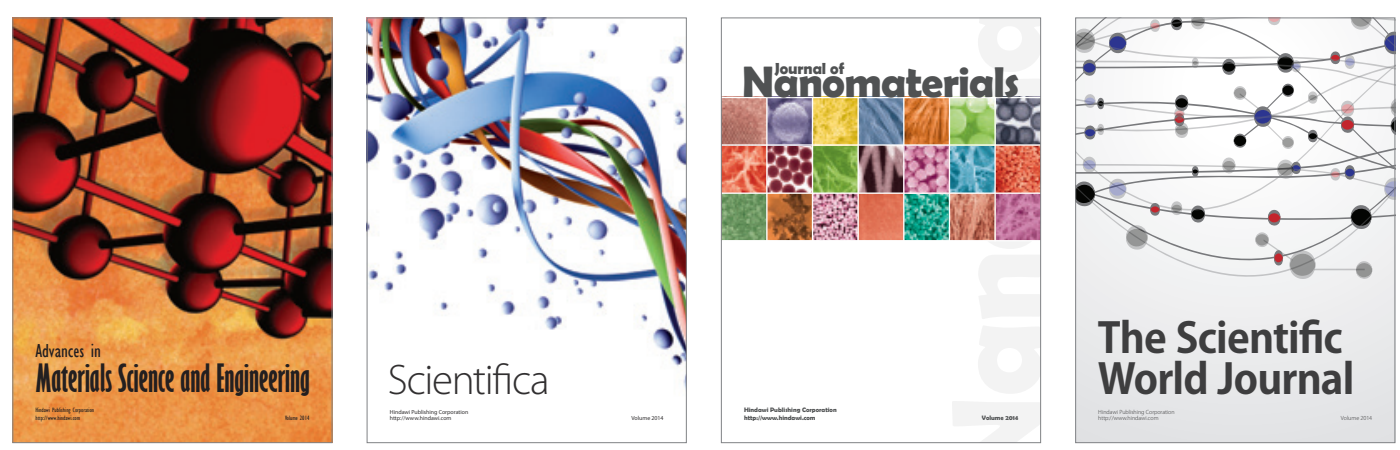

\section{The Scientific World Journal}
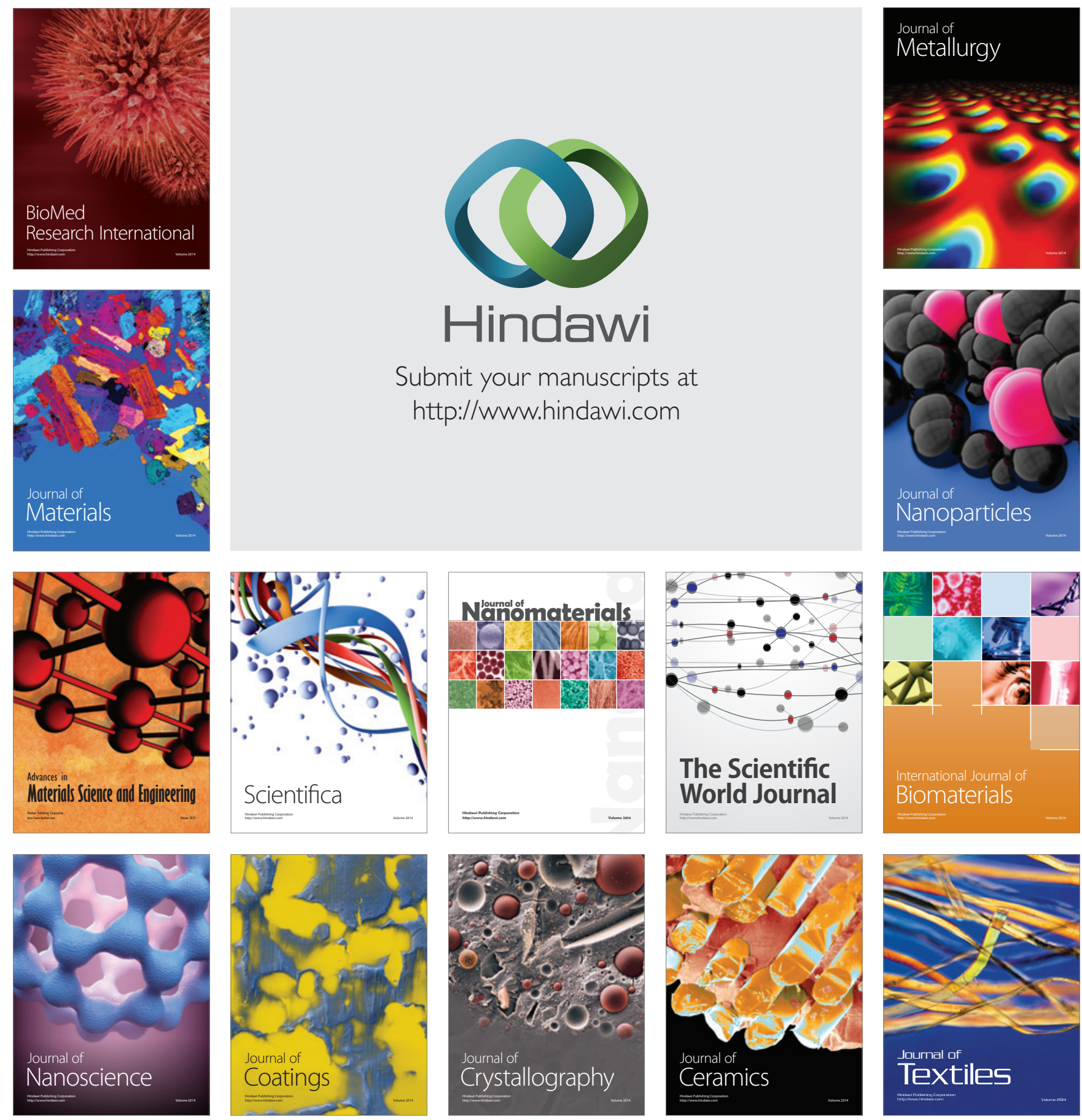